\title{
Vliv diagenetických procesů na asociaci těžkých minerálů v pískovcích z lokality Slivotín (ždánická jednotka, flyšové pásmo Vnějších Západních Karpat, Česká republika)
}

\author{
Influence of diagenetic processes on assemblage of heavy minerals in sandstones \\ from the locality Slivotín (Ždánice Unit, Flysch Belt of the Outer Western Carpathians, \\ Czech Republic)
}

\author{
ZdeněK DolníčeK ${ }^{1) *}$, Michaela KrejČí KotlánovÁ ${ }^{2,3)}$ a Rostislav KoutŇák ${ }^{4)}$ \\ ${ }^{1) M i n e r a l o g i c k o-p e t r o l o g i c k e ́ ~ o d d e ̌ l e n i ́, ~ N a ́ r o d n i ́ ~ m u z e u m, ~ C i r k u s o v a ́ ~ 1740, ~} 19300$ Praha 9 - Horní Počernice; \\ *e-mail: zdenek.dolnicek@nm.cz

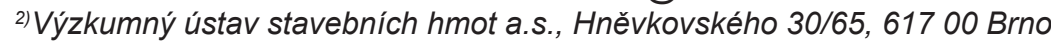 \\ ${ }^{3)}$ Masarykova univerzita, Ústav geologických věd, Kotlářská 267/2, 61137 Brno \\ 4) Bezručova 1168, 76502 Otrokovice
}

DolničEK Z, KREJČi Kotlánová M, KoutŇÁK R (2021) Vliv diagenetických procesů na asociaci těžkých minerálů v pískovcích z lokality Slivotín (ždánická jednotka, flyšové pásmo Vnějších Západních Karpat, Česká republika). Bull Mineral Petrolog 29(1): 27-40 ISSN 2570-7337

\begin{abstract}
An electron microprobe study of polished sections prepared from a sample of fine-grained sandstone from the locality Slivotín (Ždánice-Hustopeče Formation, Ždánice Unit, Flysch Belt of the Outer Western Carpathians, Czech Republic) allowed to yield in addition to data on chemical composition also the detailed information on in situ textural relationships of individual minerals. During our study, emphasis was given to accessory phases belonging to the translucent heavy mineral fraction. The detrital garnet ( $\mathrm{Alm}_{36-82} \mathrm{Grs}_{2-45} \operatorname{Prp}_{2-22} \mathrm{Sps}_{0-15}$ ) was extensively dissolved and replaced by calcite cement from its margins and along the cracks. Detrital fluorapatite was dissolved in a similar way, however, dissolution episode was followed by growth of authigenic rims composed of carbonate-fluorapatite. Other observed heavy minerals (zircon, chrome spinel, $\mathrm{TiO}_{2}$ phase, monazite, tourmaline) probably remained unaltered by diagenetic processes. The chemical composition of chrome spinels varies mostly between magnesiochromite and chromite, whereas spinel is very rare. The chemical composition of garnets and chrome spinels is comparable with published data from Czech, Polish and Slovak parts of the Flysch Belt of the Western Carpathians, and indicates the primary source of detrital material in rocks of deeper parts of orogen, characterized especially by the presence of catazonal metamorphites and almost lacking volcanic rocks. Redeposition of heavy minerals from older sediments cannot also be ruled out. The pronounced diagenetic alteration of garnet, if not very scarce in the area of Flysch Belt, could help to explain the earlier observations of wide fluctuations of contents of garnet in heavy mineral concentrates.
\end{abstract}

Key words: Outer Western Carpathians, Flysch Belt, Ždánice Unit, heavy minerals, diagenetic processes, garnet, apatite, chrome spinel

Obdrženo 10. 3. 2021; prijiato 3. 5. 2021

\section{Úvod}

Minerály s hustotou nad $2.9 \mathrm{~g} / \mathrm{cm}^{3}$ tvoři v sedimentárních horninách tzv. těžký podíl. Jeho kvantitativní zastoupení v hornině sice může významně kolísat, ale zpravidla jde o množství do 1 \% (např. Morton 1978). Studium těžkých minerálů $v$ sedimentech je $v$ současné době široce využíváno, a to nejen $v$ geologických vědách. Vedle stanovení zastoupení zrn jednotlivých minerálních fází v těžké frakci se dnes stále častěji využívá i detailního studia chemického složení jednotlivých minerálních zrn a případně i stanovení jejich radiometrického stáří. Získané výsledky jsou pak interpretovány směrem $\mathrm{k}$ identifikaci zdrojové oblasti, z níž byl derivován klastický materiál studovaných sedimentů, procesů resedimentace, možného stratigrafického zařazení studovaných sedimentů, rychlosti eroze zdrojové oblasti, směrů paleoproudění média nesoucího klastický materiál (vody, vzduchu), či podmínek a procesů při diagenezi sedimentů (např. Smale, Morton 1988; Grigsby 1990; Morton, Hallsworth 1994; Bingen et al. 2005; Fitzsimons, Hulscher 2005; Mange, Wright 2007). Příkladem využití studia těžkých minerálů $v$ negeologických oborech může být například identifikace provenience horninového materiálu z archeologických nálezů či historických staveb (např. Kropáč et al. 2004; Zapletal et al. 2012).

Studium těžkých minerálů bylo často aplikováno i při výzkumu klastických sedimentů v různých tektonických jednotkách vněkarpatského flyše. Předmětem studia zde byly vždy hrubší klastika - zejména pískovce, méně slepence. Ve starších dobách byly klasickým způsobem studovány asociace průhledných těžkých minerálů, v novějších pracích je vedle toho analyzováno i chemické složení vybraných minerálních fází, zejména granátu, turmalínu a chromspinelidů (Gilíková et al. 2002; Oszczypko, Sa- 
lata 2005; Stráník et al. 2007; Bónová et al. 2016, 2017 2018a,b, 2019). Autoři vždy konstatují v zásadě podobné základní složení průhledné těžké frakce, kdy hlavními přítomnými fázemi jsou obvykle granát, zirkon a rutil, někdy se ve významnějších množstvích vyskytují i amfiboly či turmalín. Akcesorickými komponentami jsou apatit, titanit, epidot, minerály skupiny $\mathrm{Al}_{2} \mathrm{SiO}_{5}$, staurolit či monazit. Pozoruhodné je výrazné kolísání v zastoupení hlavních průhledných těžkých minerálů. Na prííklad u granátu je uváděn rozptyl obsahů v intervalu mnoha desítek procent (např. 0 - $60 \%$ v polské části magurské jednotky; Oszczypko, Salata 2005; 0 - $81 \%$ v moravské části magurské jednotky; Gilíková et al. 2002), avšak vysvětlení možných přičin této extrémní variability citované práce většinou neuvádějí.

$V$ tomto příspěvku přinášíme bližší charakteristiku vybraných minerálů těžké frakce z pískovce z lokality Slivotín u Hulína. Zatímco všechny předchozí studie týkající se těžkých minerálů ve flyšových horninách Vnějších Západních Karpat byly založeny na výzkumu těžké frakce předem vyseparované z rozdrcené horniny, $v$ této práci jsme těžké minerály studovali in situ v horninových nábrusech. Použití tohoto odlišného prístupu přineslo velmi zajímavé výsledky, které by byly při použití obvykle využívané metodiky z větší části nezjistitelné.

\section{Lokalizace a geologická pozice}

Studovaná lokalita je situována na střední Moravě, asi $1 \mathrm{~km}$ severně od severního okraje obce Tlumačov, na hranicích obcí Tlumačov a Hulín. Místní název lokality je Slivotín a katastrálně náleží obci Hulín. Lokalitou jsou pozůstatky starého jámového lůmku na stavební kámen o hloubce $5 \mathrm{~m}$, velikosti cca $39 \mathrm{~m}$ ve směru $V-Z$ a $28 \mathrm{~m}$ ve směru S - J (obr. 1). Dle sdělení starousedlíků byly v lůmku $v$ době těžby odkryty vrstvy pískovců o mocnosti od 2 do $30 \mathrm{~cm}$, střídající se s jílovci. Pískovec byl předmětem těžby. Po jejím ukončení byly lomové stěny $z$ bezpečnostních důvodů strženy, zavezeny hlušinou pocházející z vytěženého prostoru a následně bylo vše překryto zeminou.

Lokalita byla ovzorkována u príležitosti terénních úprav souvisejících s revitalizací ploch při budování zahrady. Studovaný vzorek pískovce byl odebrán z kopané

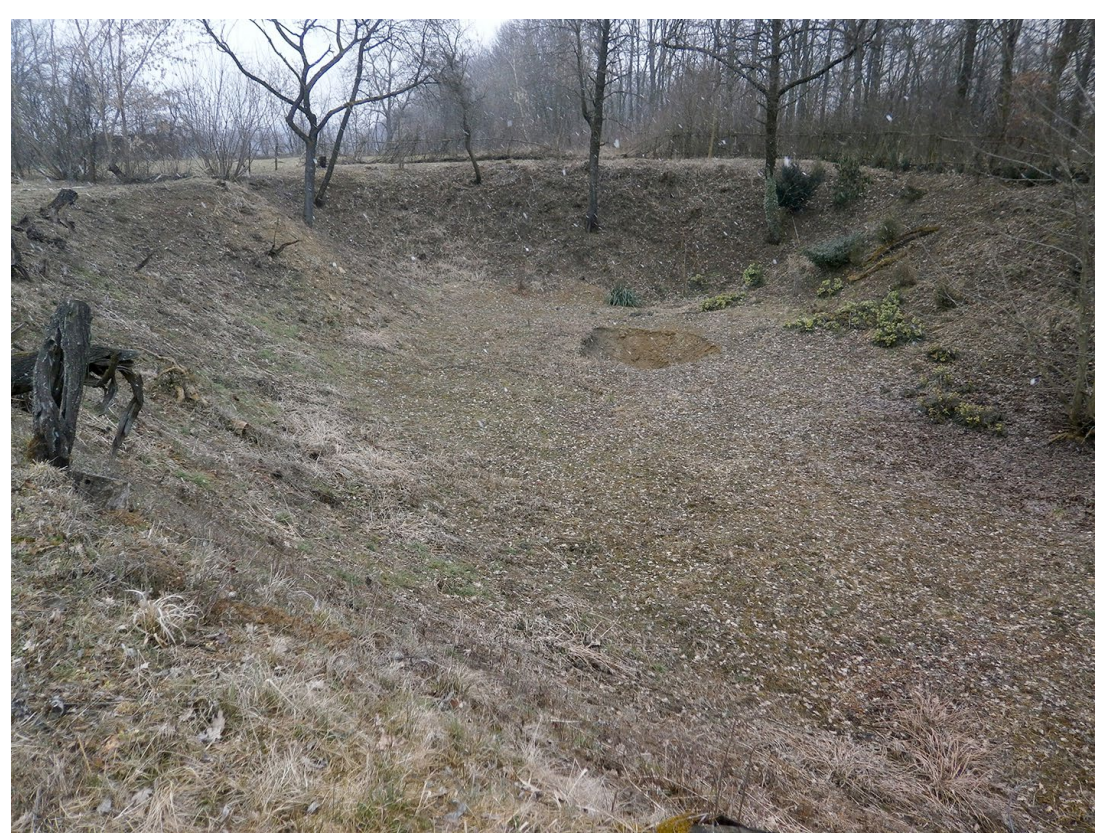

Obr. 1 Studovaná lokalita, stav v únoru 2021. Foto R. Koutňák. sondy o hloubce $1.5 \mathrm{~m}$, situované v severovýchodní části bývalého lůmku. Primární výchoz horniny nebyl zastižen. Vzorek byl odebrán z hloubky $1.3 \mathrm{~m}$ z polohy obsahující zvýšenou akumulaci úlomků pískovce.

V suti, jež překrývá lomové stěny, byly hojně nalezeny úlomky pískovců, mnohdy s patrnými mechanoglyfy, a zbytky zvětralých, silně rozpadavých jílovců. Kromě zmíněných klastických sedimentů byly zastiženy i úlomky a hlízy kalových vápenců s místy patrnými organogenními klasty. Vzácně Ize rozeznat na povrchu vápenců aptychy amonitů.

Geologicky je zájmová lokalita podle geologických map 1:200 000 a 1:50 000 situována $\vee$ horninách náležejících ždánicko-hustopečskému souvrství ždánické jednotky vněkarpatského flyšového pásma (obr. 2). Ždánická jednotka je součástí vnější (menilito-krosněnské) skupiny príkrovů, přes kterou byly v průběhu alpinských orogenních procesů přesunuty flyšové horniny vnitřní (magurské) skupiny príkrovů. Násunová plocha (magurské nasunutí) probíhá $v$ dnešním erozním řezu asi $1 \mathrm{~km}$ jižně a východně od studované lokality a je podél ní vyvlečeno i bradlo kurovických vápenců svrchnojurského až spodnokřídového stárí. Ždánicko-hustopečské souvrství je tvořeno marinními flyšovými sedimenty svchnooligocenního až spodnomiocenního stárí, charakterizovanými rytmickým střídáním vápnitých pískovců a jílovců. Lokálně obsahuje i tělesa skluzových slepenců s obsahem valounů sedimentárních hornin ze staršího magurského flyše (Stráník 1993; Chlupáč et al. 2002).

\section{Metodika výzkumu}

Odebraný vzorek byl rozřezán diamantovou pilou a z vhodných partií byly zhotoveny standardní zalévané naleštěné preparáty (nábrusy) o průměru $2.5 \mathrm{~cm}$. Prvotní dokumentace nábrusů v odraženém světle byla provedena na Mineralogicko-petrologickém oddělení Národního muzea v Praze pomocí polarizačního mikroskopu Nikon Eclipse ME 600.

Preparáty byly následně vakuově napařeny uhlíkovým filmem o tloušt'ce $30 \mathrm{~nm}$ a studovány pomocí elektronového mikroanalyzátoru Cameca SX-100 (operátor Z. Dolníček, Národní muzeum Praha). Na přístroji byly pořizeny fotografie ve zpětně odražených elektronech (BSE) a provedena identifikace jednotlivých minerálních fází pomocí rychlých energiovědisperzních (EDS) spekter. U vybraných fází bylo následně kvantitativně měřeno chemické složení ve vinově disperzním (WDS) modu.

Při kvantitativních analýzách minerálů byly použity následující podmínky: urychlovací napětí 15 $\mathrm{kV}$, proud svazku $20 \mathrm{nA}$ (spinelidy, granát), respektive $10 \mathrm{nA}$ (apatit) a průměr elektronového svazku 0.7 (spinelidy, apatit), respektive $2 \mu \mathrm{m}$ (granáty). $\mathrm{V}$ granátech byly stanovovány obsahy $\mathrm{Al}, \mathrm{As}, \mathrm{Ca}, \mathrm{Cr}, \mathrm{F}, \mathrm{Fe}, \mathrm{Mg}$, $\mathrm{Mn}, \mathrm{Na}, \mathrm{Ni}, \mathrm{P}, \mathrm{Sb}, \mathrm{Si}, \mathrm{Sn}, \mathrm{Ti}, \mathrm{U}, \mathrm{V}, \mathrm{Y}$, $\mathrm{Zn}$ a Zr, ve spinelidech obsahy $\mathrm{Al}, \mathrm{Ca}$, $\mathrm{Co}, \mathrm{Cr}, \mathrm{Fe}, \mathrm{Mg}, \mathrm{Mn}, \mathrm{Ni}, \mathrm{P}, \mathrm{S}, \mathrm{Si}, \mathrm{Ti}, \mathrm{V}$, $\mathrm{Zn}$ a $\mathrm{Zr}$ a v apatitu obsahy $\mathrm{Al}$, As, Ba, $\mathrm{Ca}, \mathrm{Ce}, \mathrm{Cl}, \mathrm{F}, \mathrm{Fe}, \mathrm{K}, \mathrm{Mg}, \mathrm{Mn}, \mathrm{Na}, \mathrm{P}$, $\mathrm{Pb}, \mathrm{S}, \mathrm{Si}, \mathrm{Sr}, \mathrm{Y}$ a Zn. Při analýzách byly použity následující standardy 
a analytické čáry: albit $(\mathrm{NaK} \alpha)$, almandin (AlKa, FeKa), antimonit $(\mathrm{Sb} L \alpha)$, apatit $(\mathrm{CaK} \alpha, \mathrm{PK} \alpha)$, baryt $(\mathrm{Ba} L \alpha)$, celestin (SKa, $\mathrm{Sr} L \beta), \mathrm{CePO}_{4}(\mathrm{Ce} L \alpha), \mathrm{Cr}_{2} \mathrm{O}_{3}(\mathrm{CrK} \alpha)$, diopsid $(\mathrm{Mg} K \alpha)$, halit $(\mathrm{CI} K \alpha)$, hematit $(\mathrm{Fe} K \alpha)$, klinoklas $(\mathrm{As} L \alpha)$, $\mathrm{LiF}(\mathrm{FK} \alpha)$, Ni $(\mathrm{Ni} K \alpha)$, rodonit $(\mathrm{MnK} \alpha)$, sanidin $(\mathrm{K} K \alpha, \mathrm{Si} K \alpha$, $\mathrm{Al} K \alpha), \mathrm{Sn}(\mathrm{Sn} L \alpha), \mathrm{TiO}_{2}(\mathrm{Ti} K \alpha), \mathrm{UO}_{2}(\mathrm{U} M \alpha), \mathrm{V}(\mathrm{V} K \alpha)$, vanadinit $(\mathrm{PbM} \alpha)$, wollastonit $(\mathrm{CaK} \alpha, \mathrm{SiK} \alpha), \mathrm{YVO}_{4}(\mathrm{Y} L \alpha)$, zinkit $(Z n K \alpha)$, zirkon $(Z r L \alpha)$. Měřící časy na píku se pohybovaly obvykle mezi 10 a $30 \mathrm{~s}$, měřící časy pozadí trvaly polovinu času měření na píku. Načtená data byla přepočíána na obsahy oxidů, vyjádřené v hm. \%, s použitím standardní PAP korekce (Pouchou, Pichoir 1985). Získaná data byla korigována na koincidence Ti vs. V, Cr vs. V, Mn vs. $\mathrm{Cr}$, P vs. Ca a F vs. Ce. Obsahy výše uvedených prvků, které nejsou uvedeny $v$ níže prezentovaných tabulkách minerálních analýz, byly ve všech případech pod mezí stanovitelnosti, která se pohybovala pro většinu prvků obvykle mezi 0.03 a $0.1 \mathrm{hm}$. \%.

\section{Výsledky}

Studovaný vzorek je tvořen rezavě hnědým jemnozrnným pískovcem (obr. 3a). Klastický materiál je zrnitostně velmi dobře vytříděný, v hornině zcela převažují klasty o velikosti mezi cca 100 a $150 \mu \mathrm{m}$, zatímco aleuriticko-pelitická matrix, stejně jako hruběji klastický (>200 $\mu \mathrm{m})$ materiál prakticky nejsou vůbec prítomny (obr. 3b). Klasty jsou tvořeny zejména křemenem, v menší míře i K-živcem, muskovitem, horninovými úlomky, vzácně i chloritizovaným biotitem a akcesoriemi (granát, apatit, chromspinel, zirkon, ilmenit, $\mathrm{TiO}_{2}$ fáze, monazit, turmalín). Autigenní fáze jsou představovány framboidálním pyritem (velmi často limonitizovaným), limonitem a glaukonitem. Tmel horniny je většinou pórový, pouze v partiích, kde byly křemenné klasty výrazněji postiženy rozpouštěním, má tmel bazální až korozní charakter (obr. 3b). Je tvořen kalcitem, který je obvykle v BSE obraze homogenní a v EDS spektru bez stop příměsí Al či Si, což nasvědčuje neprítomnosti jemné disperze detritických minerálů. Místy kalcitový tmel obsahuje obláčkovité smouhy či shluky limonitu a/nebo $\mathrm{TiO}_{2}$ fáze. Křemen vytváří izometrická zrna, u nichž je však obtižné hodnotit charakter opracování, nebot' jeho klasty byly ve větši či menší míře od okrajů zrn rozpouštěny, respektive zatlačovány kalcitovým tmelem. Nejlépe patrný je tento jev v partiích, kde má tmel bazální/korozní charakter: křemenná zrna zde mají v důsledku nerovnoměrné koroze zřetelně členité, místy až zubovité okraje (obr. 3b). U klastů živců a lupínků slíd však koroze kalcitovým tmelem zjištěna nebyla, zatímco u horninových úlomků se projevy karbonatizace také vyskytly. Někdy je natolik intenzivní, že až znemožňuje jejich petrografickou identifikaci. Karbonatizací málo postižené horninové klasty většinou odpovídají jílovci či jílové břidlici. Studo-

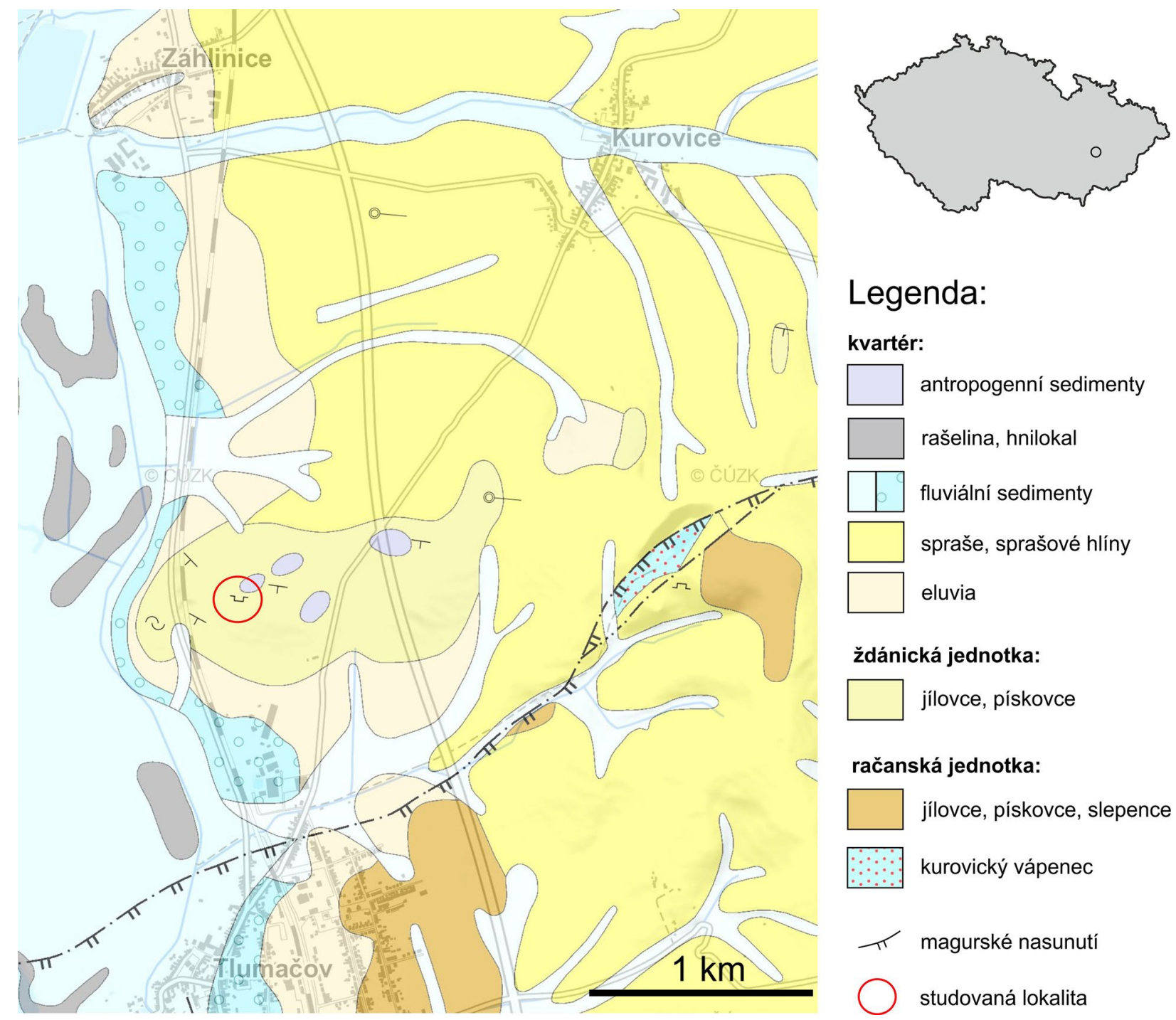

Obr. 2 Geologická pozice studované lokality. Podkladová mapa v měřitku 1:50 000 převzata z www.geology.cz. 
vanou horninu můžeme tedy označit jako jemnozrnný, zrnitostně dobře vytříděný pískovec (případně až arkózový pískovec; kvantifikace hlavních složek klastické frakce nebyla provedena) s kalcitovým tmelem.

Bližší pozornost byla věnována akcesorickým minerálům, které Ize zahrnout do kategorie průsvitné těžké frakce, tzn. granátu, apatitu, chromspinelu, zirkonu, $\mathrm{TiO}_{2}$ fázi, monazitu a turmalínu. $Z$ nich detailněji pak byly studovány jen minerály, které se vyskytly $v$ množství větším než jen velmi malém, a k nimž v literatuře již existují srovnávací data k chemismu (granát, apatit, chromspinel).

Granát je z blíže studovaných akcesorií ve studovaném pískovci nejhojnější. Jeho značně korodovaná zrna dosahuji velikosti srovnatelné s klasty křemene. Stupeň opracování nelze posoudit, vzhledem k intenzivní korozi tmelem. Téměř ve všech př́padech je původní minerál
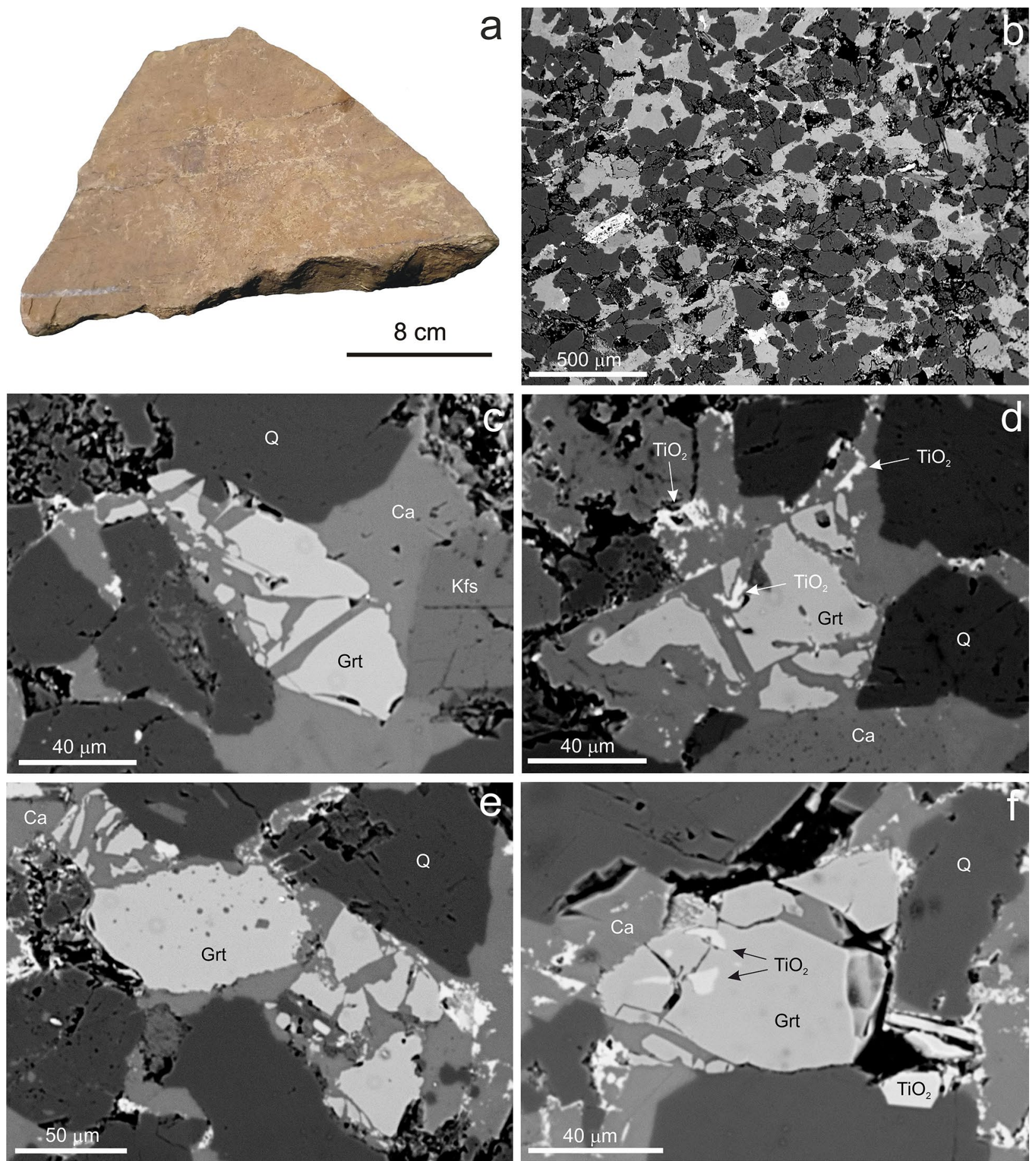

Obr. 3 Fotografická dokumentace studovaného pískovce a minerálů těžké frakce. a - makrofoto studovaného vzorku pískovce. b - stavba studovaného pískovce na BSE snímku. Klasty jsou tvořeny hlavně křemenem (černý), podřízeně i K-živci (izometrická zrna o málo tmavší než kalcit), muskovitem (lištovitá zrna o málo tmavší než kalcit), akcesorickým apatitem, TiO fází a pyritem (všechny světlé). Tmel je tvořen kalcitem. c - korodovaný granát (Grt) $v$ asociaci s křemennými (Q) a K-živcovými (Kfs) klasty a kalcitovým (Ca) tmelem. d - korodovaný granát (Grt), při jehož rozpouštění docházelo k vylučování novotvořeného $\mathrm{TiO}_{2}$ minerálu (TiO $\mathrm{T}_{2}$. e - původně dva klasty různě intenzivně korodovaného granátu (Grt). f - granát (Grt) s uzavřeninami TiO fáze. Snímek a M. Krejčí Kotlánová, BSE snímky b-f Z. Dolníček. 
přitomen jen ve shlucích drobných ostrohranných reliktů o velikosti maximálně $70 \mu \mathrm{m}$, většinou však nepřesahujících velikost $50 \mu \mathrm{m}$, rozmístěných $v$ prostoru původního granátového klastu (obr. 3c-f). Kalcitovým tmelem je granát zatlačován jak od okrajů, tak podél náhodně orientovaných nepravidelných žilkovitých proniků protínajících i vnitřní části pưvodního zrna. Kalcitové proniky se omezuji jen na granátová zrna, v klastech ostatních minerálů nejsou přítomny. $V$ místech, kde se granát prímo stýká $\mathrm{s}$ klasty dalších minerálních fází (obr. 3c, 4a), je patrné, že granát byl vůči tlakovému rozpouštění odolnější než křemen a apatit. Granát většinou neobsahuje žádné inkluze jiných minerálních fází, jen jednou byla zjištěna drobná uzavřenina minerálu ze skupiny $\mathrm{TiO}_{2}$ (obr. $3 f)$. $V$ některých případech bylo pozorováno, že během rozpouštění granátu docházelo $\mathrm{k}$ vyloučení novotvořeného $\mathrm{TiO}_{2}$ minerálu. Charakteristickým rysem je v těchto prípadech jemnozrnná stavba takových vyloučenin a jejich prostorové omezení výlučně na oblast původního klastu granátu (obr. 3d). V BSE obraze nebyla viditelná žádná zonalita granátu. Podrobně bylo studováno chemické složení granátu - celkem bylo ze tří studovaných nábrusů analyzováno 84 zrn (zrnem se $v$ tomto prípadě rozumí původní klast, nikoliv jednotlivé z něj vzniklé dílčí relikty). Pokud to velikost dovolovala, byly z každého zrna pořizeny dvě bodové WDS analýzy, z malých individuí jen jedna. Celkem bylo získáno 154 analýz, jejichž reprezentativní výběr je prezentován $v$ tabulce 1 . Klasifikač- ně jde většinou o almandiny, které obsahují zvýšenou grosulárovou, pyropovou a spessartinovou komponentu a jen nepatrné množství fluorokatoitové, andraditové, Tigranátové a případně i menzeritové(-Y) složky (Alm ${ }_{52-82}$ $\mathrm{Grs}_{2-34} \mathrm{Prp}_{2-22} \mathrm{Sps}_{0-15} \mathrm{Ti}^{-G \mathrm{Gr}_{0-3}} \mathrm{Adr}_{0-2} \mathrm{Men}_{0-2} \mathrm{~F}-\mathrm{Kat}_{0-1}$; obr. 5a). Pouze jediné zrno již odpovídá klasifikačně grosuláru $\left(\mathrm{Alm}_{36-40} \mathrm{Grs}_{42-45} \operatorname{Prp}_{3-4} \mathrm{Sps}_{9-13} F-\mathrm{Kat}_{1}\right.$; obr. 5a). Bodové analýzy potvrdily minimální zonalitu granátových zrn, rozdíly v obsazích jednotlivých koncových členů v rámci jednoho zrna granátu nikdy nepřesahují $4 \mathrm{~mol}$. \% a jen zř́idkakdy jsou vyšší než 2 mol. \%. Mezi obsahy koncových členů ve studovaných granátech neexistuji žádné zjevné závislosti (obr. 6a-c), snad jen s výjimkou dvou nejzastoupenějších složek almandinové a grosulárové (obr. 6a). Ani v tomto prípadě však nejde o závislost vysloveně velmi těsnou $\left(R^{2}=0.69\right)$. Nebylo zjištěno, že by granáty $s$ vyšším obsahem Ca vykazovaly větší intenzitu koroze.

Chromspinelid je vedlejší složkou studované asociace těžkých minerálù. Vytváří subangulární zrna o velikosti 40 - $90 \mu \mathrm{m}$, která nevykazují známky mladších alterací. Nebyly zjištěny ani žádné minerální uzavřeniny. V BSE obraze jsou většinou homogenní, jen ojediněle byly zjištěny partie s odlišným chemismem. Bodové WDS analýzy byly pořizeny $z$ celkem 10 zrn. $Z$ větších individuí byly zhotoveny dvě analýzy, z malých jen jedna. Celkem bylo získáno 17 analýz, jejichž reprezentativní výběr je prezentován $v$ tabulce 2 . Celý datový soubor vykazuje poměrně širokou variabilitu, ale jednotlivá zrna, až na jednu výjim-

Tabulka 1 Př́klady chemického složení granátu (hm. \%), koeficienty empirického vzorce vypočítané na bázi 12 atomů kyslíku a obsahy koncových členů (mol. \%). b.d. - pod mezí stanovitelnosti.

\begin{tabular}{|c|c|c|c|c|c|c|c|c|c|c|c|c|c|c|}
\hline An. č. & 1 & 2 & 3 & 4 & 5 & 6 & 7 & 8 & 9 & 10 & 11 & 12 & 13 & \\
\hline $\mathrm{P}_{2} \mathrm{O}_{5}$ & 0.04 & b.d. & b.d. & b.d. & b.d. & b.d. & b.d. & b.d. & b.d. & b.d. & b.d. & b.d. & b.d. & b.d \\
\hline $\mathrm{SiO}_{2}^{2}$ & 37.91 & 38.13 & 38.49 & 37.36 & 37.78 & 37.45 & 37.45 & 39.08 & 37.33 & 39.10 & 37.37 & 38.07 & 38.23 & 39.0 \\
\hline $\mathrm{TiO}_{2}^{2}$ & b.d. & b.d. & b.d. & 0.07 & 0.06 & b.d. & 0.11 & 0.95 & 0.06 & 0.11 & 0.11 & 0.20 & b.d. & $h$ \\
\hline $\mathrm{Al}_{2} \mathrm{O}_{3}$ & 21.53 & 22.06 & 21.86 & 21.11 & 20.88 & 21.27 & 21.12 & 21.49 & 21.30 & 21.87 & 20.95 & 21.29 & 21.65 & 21.3 \\
\hline $\mathrm{Y}_{2} \mathrm{O}_{3}$ & b.d. & b.d. & b.d. & 0.27 & 0.14 & b.d. & b.d. & b.d. & 0.72 & b.d. & b.d. & b.d. & b.d. & \\
\hline $\mathrm{MnO}^{3}$ & 1.48 & 2.00 & 0.42 & 4.80 & 0.91 & 0.13 & 6.50 & 0.56 & 5.04 & 0.17 & 3.70 & 2.81 & 2.30 & 4. \\
\hline $\mathrm{FeO}$ & 35.91 & 31.05 & 31.48 & 30.50 & 33.85 & 30.61 & 27.65 & 27.87 & 28.94 & 28.64 & 26.80 & 27.13 & 23.32 & 18.5 \\
\hline $\mathrm{MgO}$ & 2.93 & 5.57 & 4.67 & 1.04 & 1.28 & 3.85 & 1.11 & 3.88 & 0.76 & 3.90 & 2.03 & 1.44 & 2.84 & 0.1 \\
\hline $\mathrm{aO}$ & 0.59 & 1.21 & 3.79 & 4.39 & 4.73 & 5.21 & 5.86 & 7.18 & 6.46 & 6.87 & 7.68 & 8.81 & 11.03 & 16.6 \\
\hline $\mathrm{Na}_{2} \mathrm{O}$ & b.d. & b.d. & b.d. & 0.07 & b.d. & b.d. & b.d. & b.d. & 0.10 & b.d. & b.d. & 0.13 & b.d. & \\
\hline$F^{2}$ & b.d. & b.d. & b.d. & b.d. & b.d. & b.d. & b.d. & 0.08 & b.d. & b.d. & b.d. & b.d. & b.d. & \\
\hline $\mathrm{O}=\mathrm{F}$ & 0.00 & 0.00 & 0.00 & 0.00 & 0.00 & 0.00 & 0.00 & -0.03 & 0.00 & 0.00 & 0.00 & 0.00 & 0.00 & \\
\hline Celkem & 100.39 & 100.02 & 100.71 & 99.61 & 99.63 & 98.52 & 99.80 & 101.06 & 100.71 & 100.66 & 98.64 & 99.88 & 99.37 & 100.6 \\
\hline$\overline{P^{5+}}$ & 0.003 & b.d. & b.d. & b.d. & b.d. & b.d. & b.d. & b.d. & b.d. & b.d. & b.d. & b.d. & b.d. & \\
\hline $\mathrm{Si}^{4+}$ & 028 & 3.000 & 3.012 & 3.024 & 3.048 & 3.005 & 3.017 & 3.029 & 2.994 & 3.041 & 3.015 & 3.028 & 3.013 & 0 \\
\hline $\mathrm{Ti}^{4+}$ & b.d. & b.d. & b.d. & 0.004 & 0.004 & b.d. & 0.007 & 0.055 & 0.004 & 0.006 & 0.007 & 0.012 & b.d. & \\
\hline $\mathrm{Al}^{3+}$ & 2.027 & 2.046 & 2.016 & 2.014 & 1.986 & 2.012 & 2.005 & 1.963 & 2.014 & 2.005 & 1.992 & 1.996 & 2.011 & 1.9 \\
\hline $\mathrm{Y}^{3+}$ & b.d. & b.d. & b.d. & 0.012 & 0.006 & b.d. & b.d. & b.d. & 0.031 & b.d. & b.d. & b.d. & b.d. & \\
\hline $\mathrm{Mn}^{2+}$ & 0.100 & 0.133 & 0.028 & 0.329 & 0.062 & 0.009 & 0.444 & 0.037 & 0.342 & 0.011 & 0.253 & 0.189 & 0.154 & 0.2 \\
\hline $\mathrm{Fe}^{2+}$ & 2.398 & 2.043 & 2.060 & 2.065 & 2.284 & 2.054 & 1.863 & 1.806 & 1.941 & 1.863 & 1.808 & 1.805 & 1.537 & 1.2 \\
\hline $\mathrm{Mg}^{2+}$ & 349 & 0.653 & 0.545 & 0.125 & 0.154 & 0.461 & 0.133 & 0.448 & 0.091 & 0.452 & 0.244 & 0.171 & 0.334 & 0.0 \\
\hline $\mathrm{Ca}^{2+}$ & 0.050 & 0.102 & 0.318 & 0.381 & 0.409 & 0.448 & 0.506 & 0.596 & 0.555 & 0.572 & 0.664 & 0.751 & 0.932 & $1.3 \varepsilon$ \\
\hline $\mathrm{Na}^{+}$ & b.d. & b.d. & b.d. & 0.011 & b.d. & b.d. & b.d. & b.d. & 0.016 & b.d. & b.d. & 0.020 & b.d. & \\
\hline $\mathrm{F}^{-}$ & b.d. & b.d. & b.d. & b.d. & b.d. & b.d. & b.d. & 0.020 & b.d. & b.d. & b.d. & b.d. & b.d. & 0.0 \\
\hline Catsum & 7.955 & 7.977 & 7.980 & 7.965 & 7.952 & 7.989 & 7.974 & 7.935 & 7.988 & 7.950 & 7.983 & 7.972 & 7.981 & 7.9 \\
\hline Ti-Grt & 0.0 & 0.0 & 0.0 & 0.2 & 0.2 & 0.0 & 0.3 & 2.8 & 0.2 & 0.3 & 0.3 & 0.6 & 0.0 & \\
\hline Grs & 1.7 & 3.4 & 10.6 & 12.3 & 13.3 & 14.9 & 16.5 & 16.6 & 17.8 & 18.8 & 21.8 & 24.4 & 31.1 & \\
\hline Sps & 3.3 & 4.4 & 0.9 & 11.0 & 2.1 & 0.3 & 14.8 & 1.2 & 11.4 & 0.4 & 8.4 & 6.3 & 5.1 & \\
\hline Alm & 79.9 & 68.1 & 68.7 & 68.8 & 76.1 & 68.5 & 62.1 & 60.2 & 64.7 & 62.1 & 60.3 & 60.2 & 51.2 & 40 \\
\hline Prp & 11.6 & 21.8 & 18.2 & 3.8 & 4.9 & 15.4 & 4.4 & 14.9 & 2.0 & 15.1 & 8.1 & 5.7 & 11.1 & \\
\hline$F-K a t$ & 0.0 & 0.0 & 0.0 & 0.0 & 0.0 & 0.0 & 0.0 & 0.5 & 0.0 & 0.0 & 0.0 & 0.0 & 0.0 & \\
\hline Men & 0.0 & 0.0 & 0.0 & 0.6 & 0.3 & 0.0 & 0.0 & 0.0 & 1.5 & 0.0 & 0.0 & 0.0 & 0.0 & \\
\hline
\end{tabular}


ku, mají chemismus homogenní. Při přepočtu na bázi 4 atomů kyslíku a 3 kationtů Ize konstatovat, že hlavními složkami jsou $\mathrm{Cr}$ (0.88 - 1.52 apfu), Al (0.32 - 1.05 apfu), $\mathrm{Mg}(0.31-0.67 \mathrm{apfu}), \mathrm{Fe}^{2+}(0.32-0.71 \mathrm{apfu})$ a někdy i $\mathrm{Fe}^{3+}$ (max. 0.22 apfu). Obsahy Ca a Si nepresahují 0.03 apfu, obsahy Mn, Ti a V 0.013 apfu, a obsahy Zn, Ni a Co 0.007 apfu. Z diagramu pro klasifikaci chromspinelidů (obr. 6d) je patrné, že ve studovaném souboru převažuji magneziochromity nad chromity; jednoho zástupce má i spinel.

Apatit je ve studovaném pískovci přítomen ve výrazně menším množství než granát. Vytváří jednotlivá zrna, velikostně srovnatelná $s$ ostatními klasty. Jejich vnější tvar je vždy modifikován v důsledku rozpouštění, následovaného vznikem autigenních dorůstaných okrajů. Rozpouštění zrn probíhalo, zcela obdobně jako u granátů, od okrajů zrn i podél trhlin probíhajících vnitřkem zrn (obr. 4a-c). $V$ následné etapě však byly rozpuštěné partie uvnitř zrn zcela vyhojeny autigenním apatitem (obr. 4c) a dorůstání je zřetelně patrné i na okrajích zrn (obr. $4 a-c)$. Nárůsty na okrajích zrn mají někdy vůči okolnímu kalcitovému tmelu naznačeno i vlastní krystalové omezení (obr. 4b). V BSE obraze Ize rozlišit dvě etapy růstu autigenního apatitu. Starší autigenní růstová zóna (lem 1), narůstající prímo na detritické jádro, je v BSE obraze tmavší než detritický apatit, zatímco mladší autigenní růstová zóna (lem 2) je světlejší (obr. 4a-c). Chemické složení jednotlivých zón bylo ověřeno mikrosondovými analýzami, jejichž výběr je uveden $v$ tabulce 3 . Trendy ve složení jsou u všech 11 analyzovaných zrn apatitu shodné. Detritické jádro je vždy tvořeno stechiometrickým fluorapatitem (3.01 - 3.04 apfu prvků ve strukturní pozici fosforu a 0.89 - 1.22 apfu $\mathrm{F}$; báze přepočtu 5 apfu prvků ve strukturní pozici vápníku), vyznačujícím se dále uspokojivými analytickými sumami (100 \pm 0.7 hm. \%) a neobsahujícím žádnou síru a jen stopy Fe (max. 0.01 apfu) a Si (max. 0.02 apfu). Vyšší než teoretický obsah F (1 apfu), zjištěný ve většině získaných analýz, může souviset s nevhodnou orientací analyzovaných zrn (Stormer et al. 1993). Oproti tomu autigenní apatit se v obou růstových zónách vždy vyznačuje deficitem v obsazích prvků ve strukturní pozici fosforu. To nasvědčuje přitomnosti zvýšených obsahů uhlíku v jeho struktuře. Modelový dopočet obsahu uhlíku, dorovnávající zmíněný deficit, nasvědčuje př́tomnosti 0.08 až 0.27 apfu C, odpovídající 0.72 - $2.31 \mathrm{hm}$. \% $\mathrm{CO}_{2}$ (tab. 3). Obsahy fluoru jsou vždy výrazně vyšší než teoretické maximum (1.15 - 1.52 apfu; obr. 6e) a sumy analýz jsou vždy nízké (94 - 98 hm. \%). Dále Ize konstatovat ve většině analýz i zvýšené obsahy S (až 0.011 apfu; obr. 6f), Si (až 0.043 apfu; obr. 6g) a Fe (až $0.038 a p f u$ ). Mladší růstová zóna má navíc zvýšené obsahy lehkých prvků vzácných zemin (měřen pouze Ce,
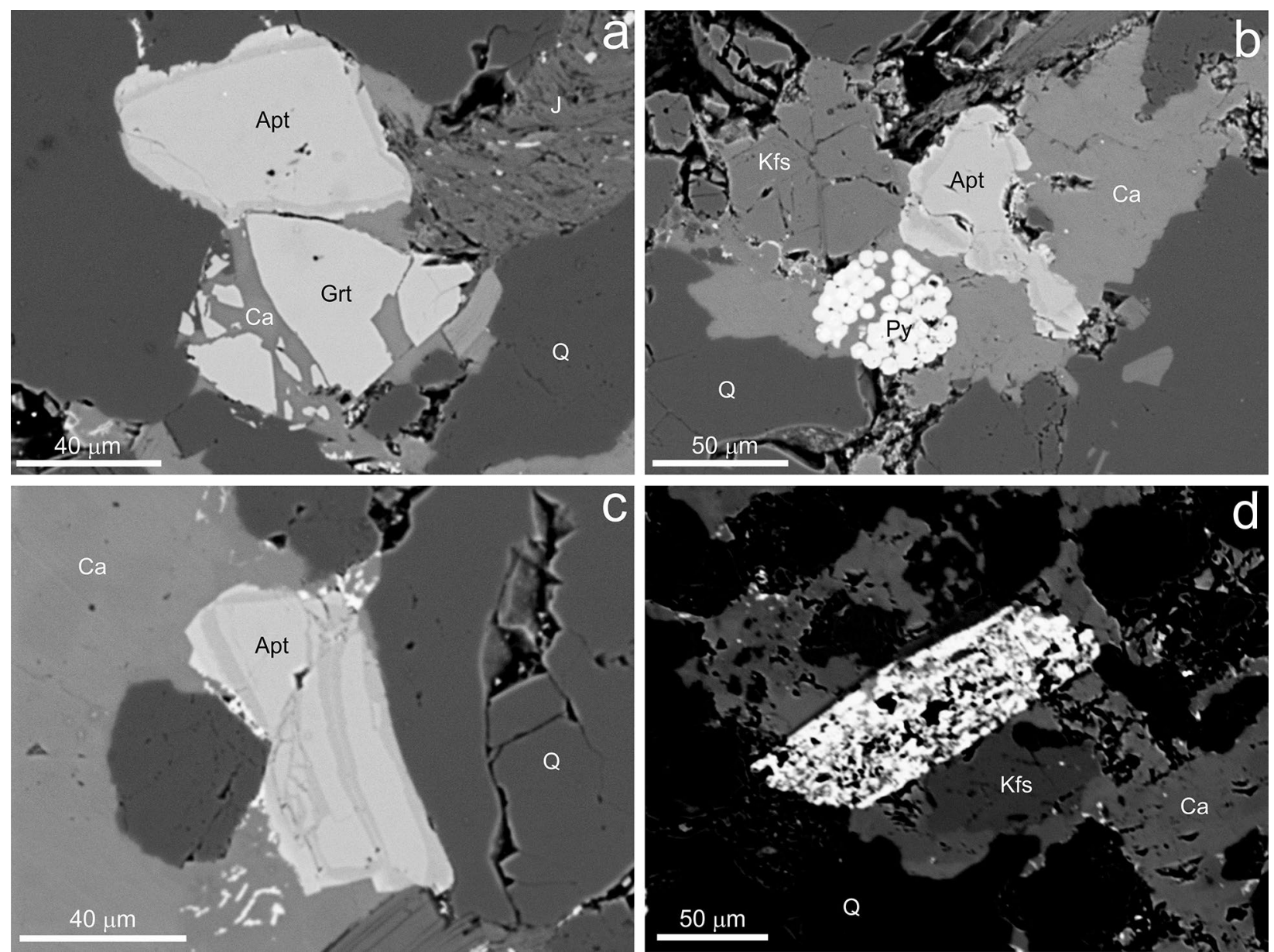

Obr. 4 Vývin některých těžkých minerálů ze studovaného pískovce na BSE snímcích. a - klast apatitu (Apt) s mladšími nárůsty (tmavši - lem 1, světlejši - lem 2) v sousedství korodovaného granátu (Grt), úlomků křemene (Q), úlomku jílovce $(\mathrm{J})$ a kalcitového tmelu $(\mathrm{Ca})$. b - rozpouštěním silně postižený apatit (Apt) s mladšími nárůsty $s$ vlastním krystalovým omezením $v$ asociaci s limonitizovaným framboidálním pyritem (Py), klastickým K-živcem (Kfs), křemenem (Q) a kalcitovým tmelem (Ca). c - apatit, postižený rozpouštěním podél prasklin a následným vyhojením. $d$ - porézní TiO ${ }_{2}$ minerál (světlý), s póry částečně vyplněnými Fe-Mg chloritem (šedý). Snímky Z. Dolníček. 
obsahy v intervalu $0.015-0.034$ apfu; obr. 6g). Autigenní zóny jsou tedy tvořeny karbonátovým aniontem bohatým fluorapatitem.

$\mathrm{TiO}_{2}$ minerál (elektronová mikroskopie a mikroanalýza neumožňuje rozlišit jednotlivé modifikace $\mathrm{TiO}_{2}$, z toho důvodu používáme skupinový název) je po granátu druhou nejzastoupenější fází $v$ rámci studované těžké frakce. Morfologicky jde o velmi proměnlivou komponentu. Část má povahu homogenních neporézních zrn o velikosti 40 - $150 \mu \mathrm{m}$, oválného až sloupečkovitého tvaru. Druhá část zrn, respektive agregátů, je polykrystalických, často i porézních. $U$ části těchto objektů nelze vzhledem $\mathrm{k}$ jejich velikosti a tvaru vyloučit možnost, že jde o pseudomorfózy po alterovaných starších Ti-minerálech (obr. 4d) či dokonce horninových klastech. Jemnozrnné porézní typy, ale menších rozměrů, se někdy vyskytuji i $v$ trhlinách kalcitem zatlačovaných granátů (obr. $3 d$ ), př́padně i v kalcitovém tmelu. Přinejmenším $v$ těchto posledně jmenovaných prípadech je pravděpodobný autigenní vznik $\mathrm{TiO}_{2}$ fáze. Podle EDS spekter obsahují homogenní zrna $\mathrm{TiO}_{2}$ fáze malé prríměsi $\mathrm{Fe}$, $\mathrm{Ca}$ a také $\mathrm{Si}$ a/nebo $\mathrm{W}$ (podle EDS spekter nelze rozhodnout, nebot' hlavní čáry obou posledně zmiňovaných prvků - WMa a SiKa - se na EDS spektrech překrývají).

Zirkon je v hodnoceném pískovci poměrně vzácným těžkým minerálem. Zrna zirkonu mají variabilní stupeň opracování, část jich je oválná, část idiomorfní, s dosud patrnými vlastními krystalovými plochami a sloupečko-

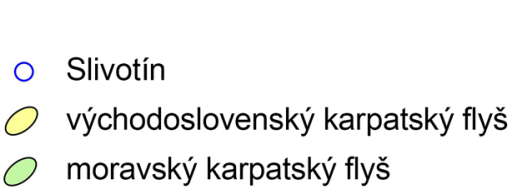

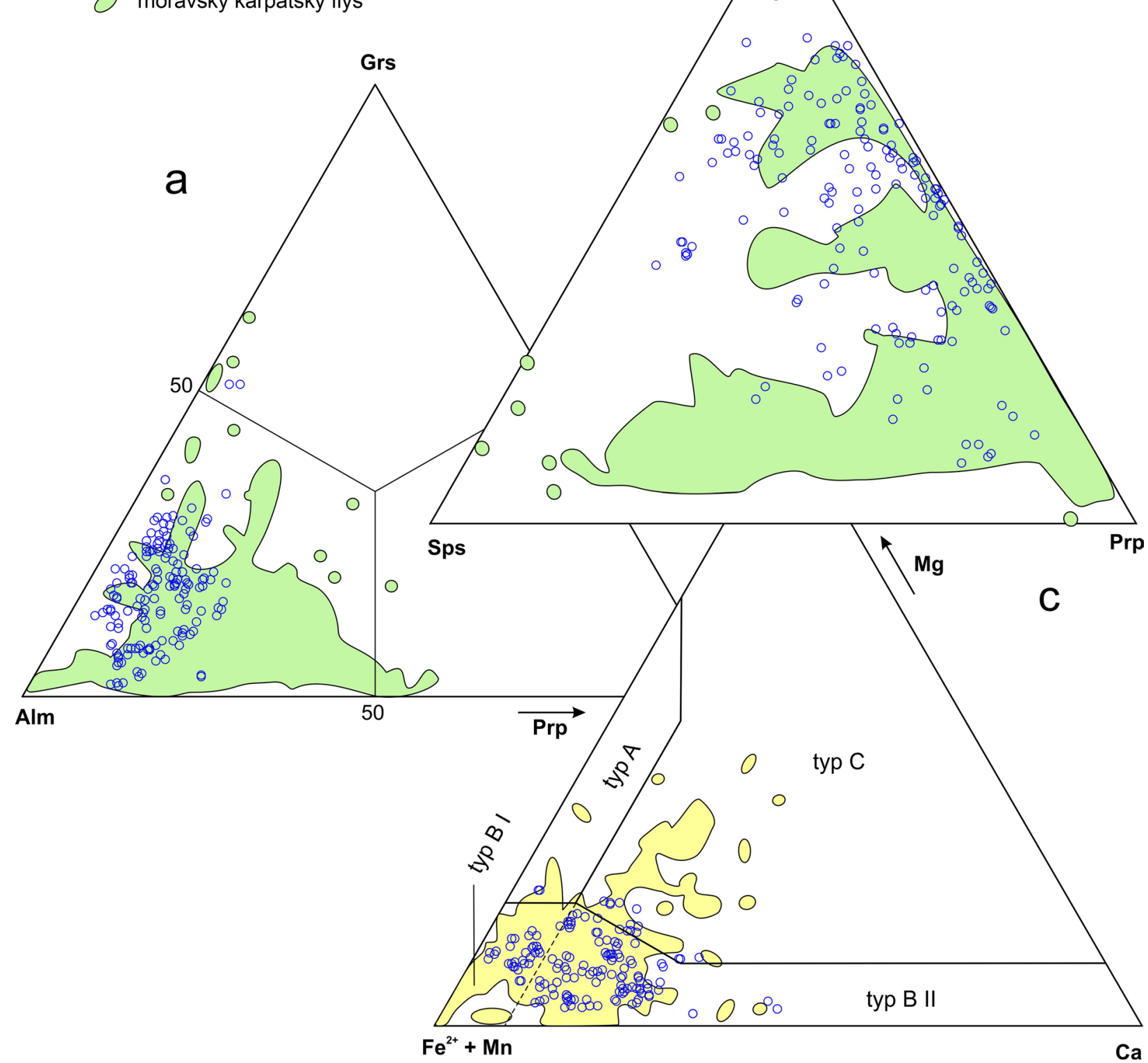

Obr. 5 Variace $v$ chemickém složení granátů z pískovce z lokality Slivotín a porovnání s publikovanými daty. a - diagram almandin-grosulár-pyrop, b - diagram spessartin-grosulár-pyrop, c - diagram ( $\left.\mathrm{Fe}^{2+}+\mathrm{Mn}\right)-\mathrm{Mg}$-Ca (Mange, Morton 2007) s vizualizací složení granátů z rưzných typů hornin: typ $A$ - granulity, typ B I - intermediální až kyselé vyvřeliny, typ B II - metasedimenty amfibolitové facie, typ C - metabazity. Srovnávací data pro moravský karpatský flyš jsou převzata z prací Otavy et al. (1997, 1998) a Stráníka et al. (2007), pro východoslovenský flyš z Bónové et al. (2016, 2018a,b, 2019). 

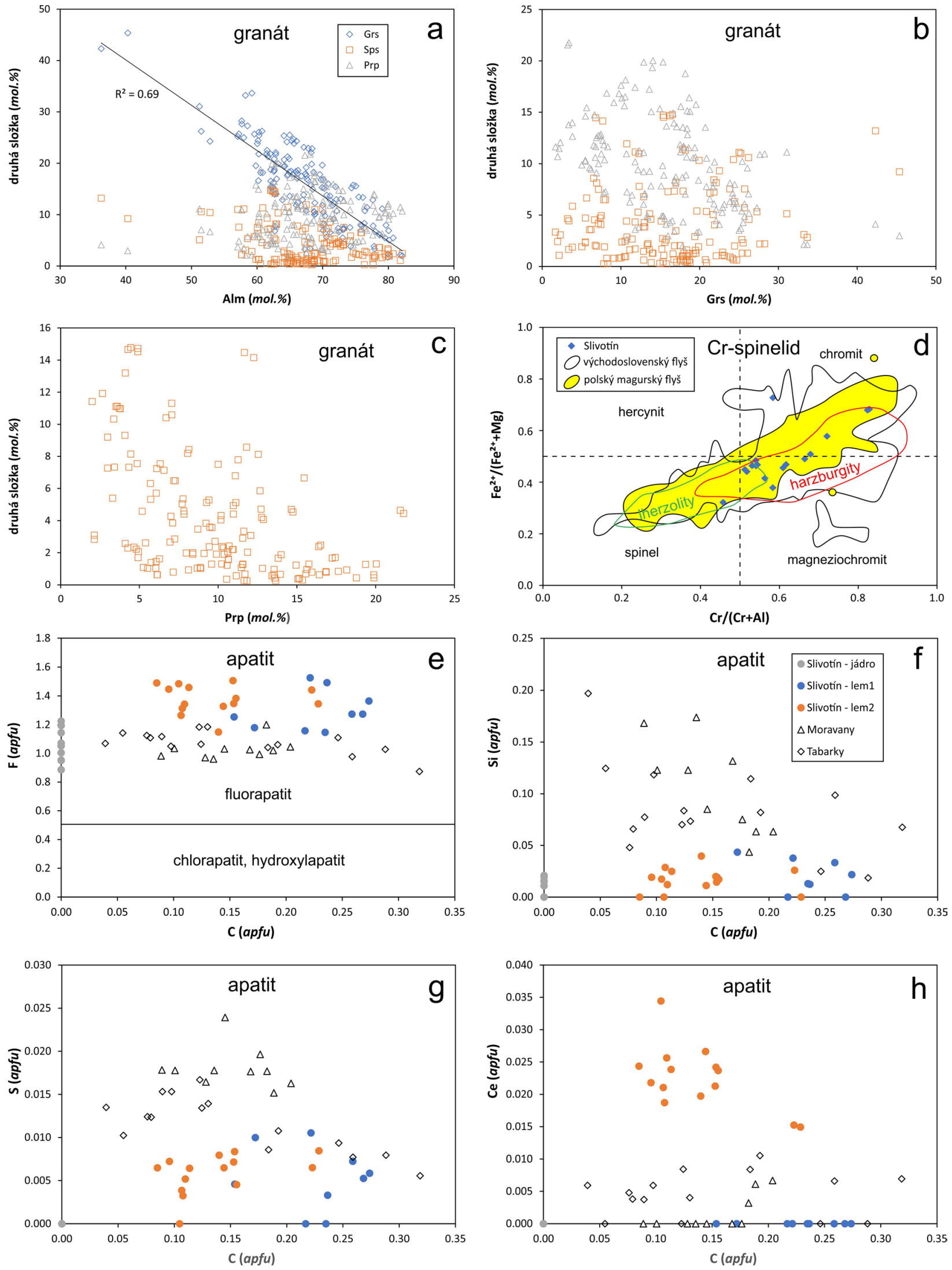

Obr. 6 Variace $v$ chemickém složení vybraných fází těžké frakce z pískovce z lokality Slivotín a porovnání s publikovanými daty. a - c vzájemné vztahy mezi obsahy čtyř nejvíce zastoupených složek v granátech. $d$ - $\mathrm{Cr} /(\mathrm{Cr}+\mathrm{Al})$ vs. $\mathrm{Fe}^{2+} /\left(\mathrm{Fe}^{2+}+\mathrm{Mg}\right)$ diagram pro chromspinelidy (Mange, Morton 2007) s vizualizací složení spinelidů z harzburgitů a Iherzolitů (Pober, Faupl 1988). e - $h$ variace $v$ chemismu detritických apatitů (jádro) a novotvořených lemů a žilek (lem1, lem2) v porovnání se složením apatitu fosforitových konkreci magurského flyše Chřibư (Tabarky, Moravany). Srovnávací data pro východoslovenský flyš jsou převzata z Bónové et al. (2016, 2017, 2018a,b, 2019), pro polský magurský flyš z Oszczypka a Salaty (2005) a pro fosfority Chřibů z Dolníčka et al. (2019, 2020). 
vitým habitem. V porovnání s klasty křemene dosahují zrna zirkonu obvykle drobnějších velikostí (30 - $80 \mu \mathrm{m})$. Známky výraznějšího rozpouštění nejsou patrné. V BSE obraze jsou zirkony homogenní i nehomogenní, v druhém případě nepravidelně skvrnitě zonální.

Monazit je vzácný, byl zjištěn jen v několika málo zrnech o velikosti $70-110 \mu \mathrm{m}$. Je subangulární, bez známek koroze, v BSE obraze nezonální. Podle EDS spekter obsahuje variabilní zvýšené obsahy Th, někdy i Ca a Si.

Turmalín byl zjištěn jen $v$ jediném zrně. Krátce sloupečkovité, subangulární, v BSE obraze nezonální individuum dosahovalo velikosti $84 \mu \mathrm{m} v$ delším rozměru. Podle EDS spektra jde o Fe-Mg turmalín se zvýšeným obsahem Ca.

$\checkmark$ levé části tabulky 4 a na obrázku 7a jsou shrnuty údaje o kvantitativním zastoupení zrn jednotlivých těžkých minerálů $v$ jednom ze studovaných nábrusů, který byl na výskyt těžkých minerálů nejbohatší. Počty zrn odrážejí pokud možno původní stav, předcházející diagenetickým alteracím. Shluky několika reliktů granátů jsou tedy počíány za 1 zrno, diageneticky vzniklé drobné porézní shluky $\mathrm{TiO}_{2}$ fáze $v$ granátech a kalcitovém tmelu nejsou započíány, ostře omezené porézní $\mathrm{TiO}_{2}$ fáze $s$ velikostí srovnatelnou se zrny ostatních klastických fází však započíány jsou. Ve studovaném pískovci je přítomna granát- $\mathrm{TiO}_{2}$-apatitová asociace těžkých minerálů, $v$ níž dominuje granát $(47 \%)$ a podstatně méně je $\mathrm{TiO}_{2}$ minerálu $(23 \%)$ a apatitu (16 \%). Každé z ostatních fází je pod $7 \%$ (tab. 4 ).

\section{Diskuse}

\section{Vliv diageneze na asociaci těžkých minerálů}

Během diageneze dochází $k$ litifikaci původně nezpevněného klastického sedimentu. I když některé diagenetické procesy mohou začínat již při velmi mělkém pohřbení a za velmi nízkých teplot (například vznik některých typů konkrecí; Raiswell, Fisher 2000), obvykle probíhají za zvýšeného tlaku a teploty a za působení chemicky aktivních roztoků. Za těchto změněných podmínek se mohou stát některé minerální fáze nestabilní a rozpouštět se, zatímco naopak jiné minerální fáze mohou nově z roztoků krystalizovat. Diagenetické procesy tedy představuji vedle charakteru zdrojových hornin, z nichž byl derivován detritický materiál, podmínek jejich zvětrávání a následného transportu a sedimentace klastického materiálu další významný faktor, který má vliv na výsledné složení asociace těžkých minerálů (např. Morton 1987; Smale, Morton 1988; Morton, Halsworth 2007).

V oblasti české části flyšového pásma Západních Karpat dosud nebyly vlivy diageneze na asociace těžkých minerálů podrobněji diskutovány. Z pískovců z různých tektonických jednotek východoslovenského karpatského flyše konstatují Bónová et al. (2016, 2018a,b, 2019) přítomnost naleptaného povrchu u řady minerálü, zejména granátu, někdy i turmalínu, zirkonu (obzvláště metamiktizovaného), rutilu a apatitu. Nejlépe patrné jsou známky rozpouštění u granátu, u něhož citovaní autoři popisuji prítomnost leptových jamek a někdy i jemně facetované-

Tabulka 2 Př́klady chemického složení chromspinelidů (hm. \%) a koeficienty empirického vzorce vypočitané na bázi 4 atomů kyslíku a 3 kationtů. b.d. - pod mezí stanovitelnosti, $\mathrm{F} / \mathrm{FM}=\mathrm{Fe} \mathrm{2}^{2+} /\left(\mathrm{Fe} \mathrm{e}^{2+}+\mathrm{Mg}\right) ; \mathrm{C} / \mathrm{CA}=\mathrm{Cr} /(\mathrm{Cr}+\mathrm{Al})$.

\begin{tabular}{|c|c|c|c|c|c|c|c|c|c|c|c|c|c|c|}
\hline An. č. & 1 & 2 & 3 & 4 & 5 & 6 & 7 & 8 & 9 & 10 & 11 & 12 & 13 & \\
\hline $\mathrm{SiO}_{2}$ & 0.33 & 0.23 & 0.63 & 0.36 & 0.24 & 0.41 & 0.74 & 0.17 & 0.44 & & & .38 & .31 & \\
\hline & b.d. & 0.50 & 0.04 & 0.06 & 0.05 & 0.16 & 0.08 & 0.05 & b.d. & 0.22 & 0.14 & 0.08 & 0.20 & \\
\hline${ }_{2} \mathrm{O}_{3}$ & 30.34 & 18.62 & 26.58 & 26.15 & 24.97 & 24.17 & 23.12 & 22.18 & 20.00 & 17.28 & 16.26 & 14.39 & 7.78 & \\
\hline $\mathrm{O}_{3}$ & .19 & 0.41 & 0.27 & 0.22 & 0.32 & 0.17 & 0.28 & 0.18 & 0.35 & 0.30 & 0.29 & 0.27 & 0.19 & 0. \\
\hline & 38.09 & 38.92 & 41.68 & 41.77 & 42.12 & 42.39 & 44.38 & 46.22 & 47.98 & 50.91 & 51.28 & 55.39 & 55.86 & 55. \\
\hline $\mathrm{e}_{2} \mathrm{O}_{3}$ & 2.24 & 8.77 & 0.00 & 0.39 & 2.36 & 2.60 & 1.17 & 2.54 & 1.24 & 1.80 & 0.68 & 0.00 & 4.76 & \\
\hline & .35 & 5.46 & 11.74 & 11.85 & 11.52 & 11.39 & 12.77 & 13.40 & 11.04 & 10.58 & 10.01 & 8.51 & 6.10 & \\
\hline & 26 & 0.54 & 0.64 & 0.75 & 0.36 & 0.81 & 0.26 & & 0.74 & & & 0.27 & 0.13 & \\
\hline & 28 & 0.42 & 0.37 & 35 & 0.32 & 37 & 0.32 & 33 & 0.37 & & 0.4 & .38 & .46 & \\
\hline & .97 & 25.88 & .02 & 69 & 17.75 & & & & & & & & 36 & \\
\hline & 08 & 06 & 0.06 & .06 & 0.07 & 06 & b.d. & b.d. & b.d. & & b.d. & 0.09 & 0.07 & \\
\hline & 12 & 12 & & 11 & & & & & & & b. & & .07 & \\
\hline & 14 & 0.26 & 0.16 & .14 & 0.19 & 0.22 & 0.20 & 0.13 & 0.13 & 0.17 & 0.22 & 0.31 & 0.24 & \\
\hline elke & .37 & 0.19 & .30 & .91 & 0.36 & & 99.57 & & 99.73 & & 8.59 & & .54 & \\
\hline & 10 & 008 & 019 & 011 & 007 & & 023 & & 0014 & & 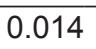 & & 011 & \\
\hline & & & & & & & & & D.d. & & & & & \\
\hline & & 21 & 956 & & & & 838 & & & & & & & \\
\hline & & & 06 & & & & & & & & & & & \\
\hline & & & 06 & & & & & & 193 & & & & 523 & \\
\hline & & & & & & & & & & & & & & \\
\hline & & & & & & & & & & & & & & \\
\hline & & 19 & 021 & 25 & 012 & & 009 & & 025 & & .016 & & 005 & \\
\hline & & 12 & 009 & 09 & & & 0.0 & 08 & & & & & & \\
\hline & & & 435 & & & & & & 0.456 & & 0.501 & & & \\
\hline & & 002 & 001 & 0.002 & & & $h d$ & b.d. & b.d. & & b.d. & 0.002 & 0.002 & \\
\hline & 03 & 003 & 003 & 0.003 & & & & 002 & 0.002 & & b.d. & b.d. & .002 & \\
\hline & 0.003 & 0.006 & 0.004 & 0.003 & 0.004 & 0.005 & 0.005 & 0.003 & 0.003 & 0.004 & 0.005 & 0.007 & 0.006 & .0 \\
\hline atsun & 3.000 & .000 & .996 & 3.000 & 3.000 & 3.000 & 3.000 & 3.000 & 3.000 & 3.000 & 3.000 & 2.996 & 3.000 & 0.4 \\
\hline & & & & & & & & & & & & 0.578 & 0.682 & \\
\hline $\mathrm{C} / \mathrm{CA}$ & 0.457 & 0.584 & 0.513 & 0.517 & 0.531 & 0.541 & 0.563 & 0.583 & 0.617 & 0.664 & 0.679 & 0.721 & 0.828 & 0.8 \\
\hline
\end{tabular}


ho povrchu zrn, které svědčí o slabém rozpouštění tohoto minerálu. Vzhledem ke společnému výskytu granátových zrn jak s naleptaným, tak i nenaleptaným povrchem však autoři v některých případech uvažují, že naleptání povrchu granátů nesouviselo $s$ diagenetickými procesy (Bónová et al. 2016), jindy však připouštějí souvislost korozních jevů s diagenetickými procesy (Bónová et al. 2018a, 2019). Situace je komplikována skutečností, že autoři ke studiu použili i těžké podíly vyrýžované ze zvětralin flyšových sedimentů (u nichž nelze vyloučit určitou korozi během naložených zvětrávacích procesů) a původ materiálu popisovaného $v$ prríslušné pasáži textu již explicitně nespecifikují.

$V$ námi studovaném vzorku můžeme konstatovat u některých minerálů nepochybnou výraznou diagenetickou alteraci. Nejnápadněji je tato alterace pozorovatelná u granátu, který vykazuje známky velmi výrazného rozpouštění. Na rozdíl od výše citovaných prací, které popisují pouze slabé projevy rozpouštění povrchu granátových zrn, bylo $v$ námi studovaném materiálu běžně pozorováno i pokročilé rozpouštění vnitřních partií zrn, spojené s jejich zatlačováním kalcitem. Vzhledem k naprosto náhodné prostorové orientaci kalcitových „žilek“ a proniků (obr. 3c-f, 4a) nelze předpokládat jejich vznik selektivním rozpouštěním růstových zón s odlišným chemickým složením; existenci chemické zonálnosti granátů ostatně nepotvrzuji ani provedené bodové analýzy. Skutečnost, že jsou kalcitové proniky prostorově omezeny jen na zrna granátu a nepokračují do sousedících klastů jiných minerálů, vylučují i možnost tektonického původu trhlinek, podél nichž rozpouštění probíhalo. Předpokládáme tedy, že rozpouštění sledovalo pre-existující mikroskopické prasklinky („pera“) uvnitř zrn. U některých zrn Ize během rozpouštění odhadovat ztrátu až poloviny objemu původního klastu granátu. Vzhledem $\mathrm{k}$ tomu, že relikty původního granátu zůstaly $v$ prostoru původního detritického zrna, můžeme předpokládat, že $\mathrm{k}$ rozpouštění granátu došlo během vzniku kalcitového tmelu horniny, který fragmenty granátu fixoval v původní pozici. Na stabilitu granátu během diageneze nejsou $v$ literatuře jednotné názory. Tvrzení, že granáty s vyšším obsahem Ca jsou více náchylné k diagenetickému rozpouštění (Morton, Hallsworth 2007), nemůžeme v námi studovaném materiálu potvrdit.

Podobně výrazná diagenetická alterace je ve studovaném pískovci zřetelně patrná u apatitu, u něhož byla iniciální fáze charakterizována podobně jako u granátu výrazným rozpouštěním od okrajů i podél trhlin, které bylo ovšem později vystř́íáno růstem autigenního apatitu (obr. 4a-c). Že se jednalo o proces diagenetického dorůstání (tedy in situ v hostitelském sedimentu) a ne o proces předcházející sedimentaci klastického materiálu, je jasně patrné jak z texturní charakteristiky nárůstů, tak i z jejich chemického složení. Texturně jde vždy o vnější lemy, kopírující obvody detritických zrn, někdy navíc s na-

Tabulka 3 Přiklady chemického složení apatitu (hm. \%) a koeficienty empirického vzorce vypočitané na bázi 5 kationtů v pozici vápníku. * - obsah $\mathrm{CO}_{2}$ dopočten na $S+P+S i+C=3$ apfu. b.d. - pod mezi stanovitelnosti.

\begin{tabular}{|c|c|c|c|c|c|c|c|c|c|c|c|c|c|c|}
\hline $\begin{array}{l}\text { n. č. } \\
\text { ozice }\end{array}$ & $\begin{array}{r}1 \\
\text { jádro }\end{array}$ & $\begin{array}{r}2 \\
\text { jádro }\end{array}$ & $\begin{array}{r}3 \\
\text { jádro }\end{array}$ & $\begin{array}{r}4 \\
\text { dro }\end{array}$ & $\begin{array}{r}5 \\
1\end{array}$ & $\begin{array}{r}6 \\
1\end{array}$ & $\begin{array}{r}7 \\
1\end{array}$ & $\begin{array}{r}8 \\
\text { em } 1 \\
\end{array}$ & $\begin{array}{r}9 \\
1 \\
\end{array}$ & $\begin{array}{r}10 \\
\text { lem } 2 \\
\end{array}$ & $\begin{array}{r}11 \\
\text { lem } 2 \\
\end{array}$ & $\begin{array}{r}12 \\
\text { lem } 2 \\
\end{array}$ & $\begin{array}{r}13 \\
\text { em } 2 \\
\end{array}$ & m 2 \\
\hline $\mathrm{O}_{3}$ & d. & b.d. & b.d. & & & & & & 0.07 & & & & & \\
\hline${ }_{2} \mathrm{O}_{5}^{3}$ & 2.35 & 2.31 & 2.20 & 42.31 & 36.74 & 36.74 & 36.77 & 36.94 & 38.19 & 37.59 & 38.74 & 37.63 & 39.76 & 39.04 \\
\hline $\mathrm{iO}_{2}$ & b.d. & b.d. & b.d. & 0.19 & 0.25 & 0.14 & & 0.49 & 0.22 & & & & b.d. & 0.20 \\
\hline $\mathrm{O}_{2}^{*}$ & & & & & 2.31 & 1.96 & .85 & 1.42 & 1.29 & 1.16 & 1.22 & 1.93 & 0.72 & 0.88 \\
\hline $\mathrm{O}_{3}$ & b.d. & b.d. & b.d. & b.d. & & & & & & & & b.d. & 0.11 & 0.25 \\
\hline $\mathrm{e}_{2} \mathrm{O}_{3}$ & b.d. & b.d. & b.d. & b.d. & b.d. & b.d. & b.d. & b.d. & b.d. & & & & & 1.08 \\
\hline & 55.27 & 55.47 & 55.09 & 55.24 & 53.36 & 52.39 & 53.02 & 52.21 & & & & & & 52.46 \\
\hline nO & b.d. & b.d. & b.d. & 0.46 & & & & b.d. & & & & & & b.d. \\
\hline $\mathrm{O}$ & 0.16 & b.d. & b.d. & b.d. & & & & & & & & & & 0.16 \\
\hline $\mathrm{a}_{2} \mathrm{O}$ & b.d. & b.d. & b.d. & b.d. & & b.d. & & b.d. & & & & 0.24 & 0.25 & 0.29 \\
\hline $\mathrm{O}$ & b.d. & b.d. & b.d. & b.d. & & & & b.d. & b.d. & b.d. & & b.d. & & b.d. \\
\hline & 3.77 & 3.33 & 4.57 & 3.59 & & & & 4.20 & & & & & & 5.39 \\
\hline & & 0.07 & & & & b.d. & & b.d. & & b.d. & & b.d. & b.d. & b.d \\
\hline$=F+$ & 59 & -1.42 & -1.92 & & & & & & & & & & & .27 \\
\hline elke & 9.96 & 9.76 & 99.94 & 0.49 & & & & 94.15 & & & & & & 7.48 \\
\hline & $d$ & $d$ & $d$ & d & & & & & & & & & & b.d \\
\hline & .021 & 3.014 & 3.027 & & & & & & & & & & & 878 \\
\hline $4^{4+}$ & $b d$ & b.d. & b.d. & 0.016 & & & & & & & & b.d. & b.d. & 017 \\
\hline & & & & & & & & & & & & & & 105 \\
\hline ubtot. & 21 & 3.014 & 3.027 & 22 & 3.000 & 3.000 & 3.000 & 3.000 & 3.000 & 3.000 & 00 & 3.000 & 3.000 & 3.000 \\
\hline $3+$ & b.d. & b.d. & b.d. & b.d. & b.d. & b.d. & b.d. & b.d. & b.d. & b.d. & & b.d. & & 0.012 \\
\hline & & & & & & & & & & & & & & \\
\hline $2+$ & .989 & 5.000 & 5.000 & & & & & 4.962 & & & & & & 4.893 \\
\hline$n^{2+}$ & & b.d. & b.d. & 0.033 & & & & & b.d. & b.d. & b.d. & & b.d. & b.d \\
\hline & & b.d. & b.d. & & & & & & & & & & .d. & .01 \\
\hline & & b.d. & b.d. & & & & & & & b.d. & 0.022 & & & 0.049 \\
\hline & & b.d. & b.d. & hd & & & & b.d. & b.d. & b.d. & b.d. & b.d. & b.d. & b.d \\
\hline uht & 000 & 5.000 & 5.000 & .000 & .000 & 5.000 & 5.000 & 5.000 & 5.000 & 5.000 & 5.000 & 5.000 & 5.000 & 5.000 \\
\hline & .004 & 0.886 & 1.224 & .953 & 1.364 & 1.492 & 1.525 & 1.178 & & 1.148 & 1.327 & 1.344 & 1.489 & 1.484 \\
\hline & b.d. & 0.010 & b.d. & 0.039 & b.d. & b.d. & b.d. & b.d. & 0.005 & b.d. & b.d. & b.d. & b.d. & \\
\hline
\end{tabular}


značeným vlastním krystalovým omezením. Chemické složení novotvořených lemů Ize velmi dobře porovnat se složením apatitu fosforitových konkrecí, které se někdy ve flyšových souvrstvích Vnějších Karpat vyskytují (např. Matýsek, Skupien 2005; Matýsek, Bubík 2012; Dolníček et al. 2019, 2020). Také v těchto prípadech jde o karbonátem bohaté fluorapatity, s príměsemi $\mathrm{S}$, Si a Fe (obr. 6e-h). Shodným znakem jsou i snižené analytické sumy WDS analýz, které mohou souviset $s$ mechanismem vzniku autigenního apatitu - někteří autoři předpokládají v iniciální fázi vysrážení nestabilního gelu fosforečnanu vápenatého, který je následně postupně transformován ve fluorapatit prijetím fluoridových a karbonátových aniontů během následné dlouhodobé interakce s pórovými vodami (Slansky 1986; Froelich et al. 1988; Stalder, Rozendaal 2004). Snížené sumy analýz tedy mohou souviset $s$ jemně porézním charakterem nově vzniklé fáze, který by mohl být důsledkem dehydratace takové gelové substance.

Diagenetické rozpouštění všech zbývajících zjištěných fází těžké frakce nelze na základě našich pozorování doložit. Je třeba ovšem poznamenat, že studium nábrusů není pro identifikaci eventuálních slabých projevů povrchové koroze minerálních zrn vhodnou metodou. Neprímo Ize ve studovaném vzorku uvažovat i o slabé korozi monazitu, a to s ohledem na zvýšené obsahy REE v mladší růstové zóně autigenního apatitu.

Vedle apatitu pri diagenetických procesech nepochybně vznikal i novotvořený $\mathrm{TiO}_{2}$ minerál. Titan pro jeho tvorbu pocházel z granátu (obr. 3d) či dalších minerálních (ilmenit?) nebo horninových klastů. Tento prvek byl během diagenetických procesů v podstatě imobilní, nebot' novotvořené $\mathrm{TiO}_{2}$ fáze jsou svým výskytem omezeny jen na prostor původních alterovaných klastů. Toto zjištění je ovšem zcela $v$ souladu $s$ obecnými geochemickými poznatky.

Získané poznatky o diagenetické alteraci některých těžkých minerálů $v$ sobě nesou i konsekvence ohledně otázky reprezentativnosti klasických analýz těžké minerální frakce, které jsou založeny na počítání zrn v koncentrátech, získaných z rozdrcené horniny. Pochybnost navíc umocňuje i fakt, že metodika, použitá pro pískovce různými autory, není jednotná. $V$ případě analýz východoslovenských výskytů byla studována prachová zrnitost-

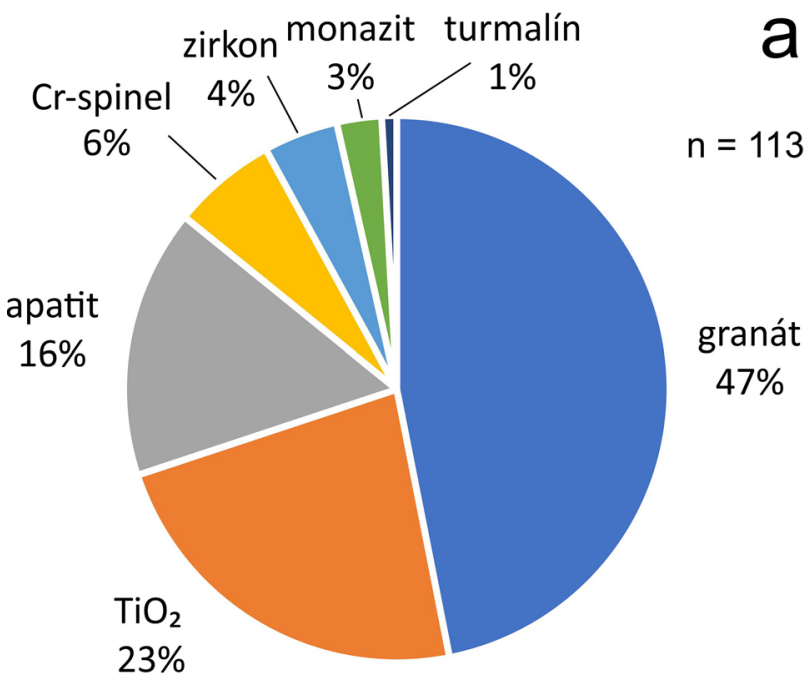

ní frakce (0.01 - 0.063 mm; Bónová et al. 2016, 2017) či prachovo-písčitá frakce $(0.01-0.5 \mathrm{~mm}$; Bónová et al. 2018a,b, 2019), zatímco v prípadě českých (Otava et al. 1997, 1998, Stráník et al. 2007) a polských (Oszczypko, Salata 2005) lokalit byla studována jemně písčitá frakce (0.06 - $0.13 \mathrm{~mm}$, Oszczypko, Salata 2005; 0.06 - 0.25 mm, J. Otava, osobní sdělení 2021). Pomineme-li možnost zvýšení počtu zrn těžkých minerálů $v$ důsledku př́liš jemného mletí, při němž dochází $k$ výraznému drcení $i$ klastických zrn psamitické frakce, v kontextu dat získaných v rámci této práce je zřejmé, že kvantitativní zastoupení zrn jednotlivých minerálů bude významně ovlivněno i aktuální velikostí jednotlivých minerálních zrn. V případě, že by z námi studovaného pískovce byla studována zrnitostní frakce $0.06-0.25 \mathrm{~mm}$, tak se složení těžké frakce výrazně ochudí o granát, nebot' diagenetická alterace způsobila fragmentaci většiny původních zrn granátu na menší zrna, jejichž velikost ve většině případů nedosahuje ani $50 \mu \mathrm{m}$, a které se tedy do studované těžké frakce nedostanou. Složení asociace se tak poměrně výrazně změní, protože ostatní minerály rozpouštěny nebyly (pravá část tab. 4 , obr. $7 b$ ). Pokud by byla $z$ námi studované horniny studována prachová frakce drti, dojde naopak ke zmnožení obsahu granátu, jehož jednotlivé relikty, vzniklé

Tabulka 4 Kvantitativní složení asociace těžkých minerálů ve vzorku pískovce FR-1d. 1 - počty zrn a přepočet na \% odrážející původní stav (tj. každý shluk reliktů granátu je počítán za 1 zrno); 2 - aktuální stav, započitána všechna individua s minimální velikostí $60 \mu \mathrm{m}$. ZTR - index zirkon-turmalín-rutil.

\begin{tabular}{lrrrr}
\hline Minerál & $1-\mathrm{ks}$ & $1-\%$ & $2-\mathrm{ks}$ & $2-\%$ \\
\hline granát & 53 & 46.9 & 8 & 13.8 \\
$\mathrm{TiO}_{2}$ & 26 & 23.0 & 20 & 34.5 \\
apatit & 18 & 15.9 & 17 & 29.3 \\
chromspinel & 7 & 6.2 & 5 & 8.6 \\
zirkon & 5 & 4.4 & 4 & 6.9 \\
monazit & 3 & 2.7 & 3 & 5.2 \\
turmalín & 1 & 0.9 & 1 & 1.7 \\
\hline celkem & 113 & 100 & 58 & 100 \\
\hline ZTR & & 28.3 & & 43.1 \\
\hline
\end{tabular}

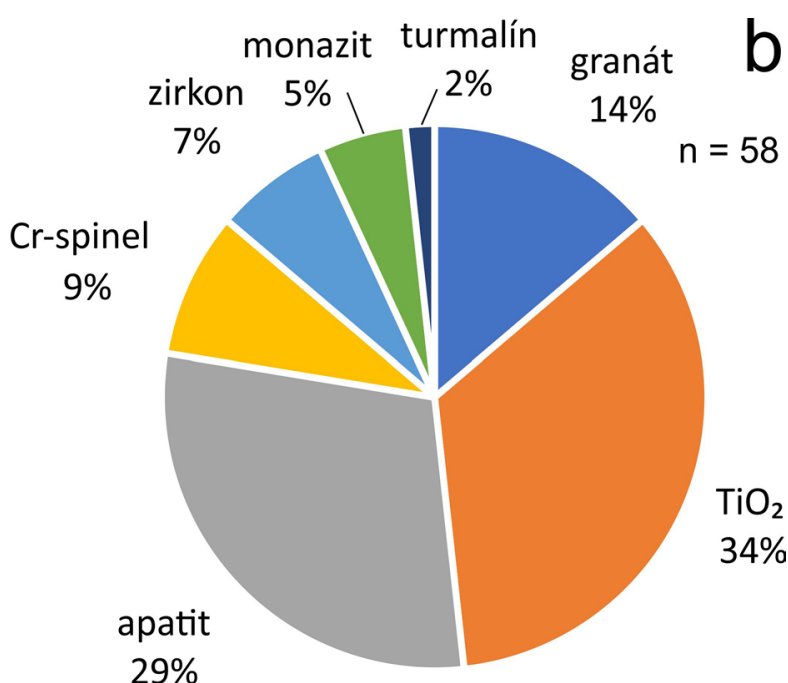

Obr. 7 Koláčové grafy ilustrující složeni průhledné těžké frakce z pískovce z lokality Slivotín. a - původní stav (tj. každý shluk reliktů granátu je počitán za 1 zrno). b - aktuální stav, započítána všechna individua s minimální velikostí $60 \mu \mathrm{m}$. 
diagenetickým rozpouštěním, většinou spadají právě do prachové frakce. Je otázkou, zdali by toto „umělé" zvýšení počtu zrn granátu bylo kompenzováno nárůstem počtu zrn i ostatních minerálů $v$ důsledku príliš jemného mletí; minimálně $v$ prípadě minerálů př́tomných jen $v$ drobnějších zrnech ( $v$ našem prípadě např. zirkon) by tomu tak nebylo. Z uvedeného vyplývá, že výsledky klasických analýz těžké frakce mohou být někdy výrazně ovlivněny použitou metodikou, a že je třeba je interpretovat obežretně, obzvláště $v$ príípadech, kdy nemáme ani rámcovou představu o možné postdepoziční alteraci př́tomných minerálních fází. Novou otázkou pro budoucí výzkumy, vyplývající z našich zjištění, tedy je, zda silně variabilní obsahy granátu $v$ těžkých podílech, popisované z české i polské části karpatského flyšového pásma (Gilíková et al. 2002; Oszczypko, Salata 2005), nemohou být alespoň v některých př́padech zapříciněny procesy intenzivní diagenetické alterace tohoto minerálu, podobně jako na námi studované lokalitě.

\section{Poznámky k provenienci}

Chemické složení některých minerálních fází těžkého podílu bývá využíáno pro interpretaci jejich možného zdroje. $V$ české, polské i slovenské části vněkarpatského flyše byl v minulosti studován chemismus detritických granátů, turmalínů a chromspinelů (Otava et al. 1997, 1998; Oszczypko, Salata 2005; Stráník et al. 2007; Bónová et al. 2016, 2017, 2018a,b, 2019). Porovnání s těmito publikovanými údaji ukazuje (obr. $5,6 \mathrm{~d}, 8$ ), že se chemické složení námi studovaných granátů a chromspinelidů nijak výrazně neodlišuje. Jak vyplývá z diagramů (obr. 5, 6a-c), granáty vykazují polymiktní složení s převahou almandinu a variabilními menšími obsahy grosulárové, spessartinové a pyropové složky. Takové granáty jsou charakteristické pro různé typy hornin metamorfovaných v amfibolitové, granulitové či eklogitové facii (ruly, migmatity, leukokratní granulity); Ca-bohatší typy mohou pocházet z méně metamorfovaných hornin (svory), z amfibolitů nebo tmavých granulitů, pyropovou složkou bohatší typy z metabazitů (Bónová et al. 2016, 2018a; srov. též obr. $5 b)$. Vyloučit nelze ani redepozici ze starších sedimentů (Otava et al. 1997, 1998; Stráník et al. 2007). Námi studované chromspinelidy mají většinou jen nízké obsahy $\mathrm{TiO}_{2}$ indikující jejich původ $v$ hlubinných horninách typu peridotitů (obr. 8), přičemž většina analýz spadá do pole harzburgitů a jen ojediněle do pole Iherzolitů (obr. 6d). Vulkanický chromspinelid je zastoupen jen jediným zrnem. Ani složení spinelidů nevybočuje z rozsahů dat publikovaných pro další oblasti vněkarpatského flyše (obr. 6d, 8). Na základě chemismu detritických fází lze (při vědomí malého množství analýz) danou asociaci celkově hodnotit jako primárně derivovanou z horninového terénu, který reprezentuje relativně hlouběji denudovanou část orogénu, a to vzhledem k téměř úplné absenci Mn-bohatších almandinů (pocházejících z granitů či pegmatitů) a Ti-bohatších chromspinelidů (pocházejících $\mathrm{z}$ vulkanických hornin).

\section{Závěr}

Studium nábrusů ze vzorku jemnozrnného flyšového pískovce z lokality Slivotín u Hulína (ždánicko-hustopečské souvrství, ždánická jednotka, flyšové pásmo Vnějších Západních Karpat, Česká republika) pomocí elektronové mikrosondy umožnilo získat vedle údajů o chemickém složení i predstavu o in situ texturních vztazích jednotlivých minerálů. Dưraz byl prítom kladen na akcesorické minerály, spadající do kategorie průhledné těžké frakce. Bylo zjištěno, že detritický granát $\left(\mathrm{Alm}_{36-82} \mathrm{Grs}_{2-45} \operatorname{Prp}_{2-22} \mathrm{Sps}_{0-15}\right.$ ) byl od okrajü a podél trhlin intenzivně rozpouštěn a zatlačován kalcitovým tmelem. Podobně byl alterován i detritický fluorapatit, jehož rozpouštění však bylo následováno růstem autigenních lemů tvořených karbonát-fluorapatitem. Další zjištěné fáze (zirkon, chromspinelid, $\mathrm{TiO}_{2}$ fáze, monazit, turmalín) zůstaly během diagenetických procesů pravděpodobně $v$ zásadě nedotčeny. Chemické složení chromspinelidů varíruje mezi 60 magneziochromitem a chromitem, ojediněle i spinelem. Chemické složení granátů a chromspinelidů je srovnatelné s publikovanými údaji z české, polské i slovenské části flyšového pásma Západních Karpat, a indikuje primární zdroj detritického materiálu $v$ horninách hlubších partií orogénu, ke provincie, OIB - bazalty oceánských ostrovu, ARC - bazalty ostrovnich oblouku, $B A B B$ - bazalty zaobloukových pánví. Srovnávací data pro východoslovenský flys jsou z Bónové et al. (2016, 2017, 2018b), pro polský magurský flyš z Oszczypka a Salaty (2005). 
charakterizovaných hlavně prítomností katazonálních metamorfitů a nedostatkem vulkanických hornin. Možná je i redepozice těžkých minerálů ze starších sedimentů. Významná diagenetická alterace granátu, pokud by v oblasti flyšového pásma nebyla jen ojedinělá, by mohla pomoci vysvětlit velmi výrazné kolísání obsahů tohoto minerálu $v$ koncentrátech těžkých minerálů, zjištěné při dřívějších výzkumech.

\section{Poděkování}

Studium granátů bylo provedeno za finanční podpory Ministerstva vnitra ČR v rámci projektu VI20192022148 (Komplexní instrumentální metodika pro charakterizaci vybraných minerálních fází s vazbou na konkrétní geografický pưvod), výzkum ostatních minerálních fází byl realizován za finanční podpory Ministerstva kultury Č $R$ $\checkmark$ rámci institucionálního financování dlouhodobého koncepčního rozvoje výzkumné organizace Národní muzeum (DKRVO 2019-2023/1.II.c, 00023272). J. Otavovi (ČGS Brno) děkujeme za informaci ohledně metodiky použité při studiu těžké frakce moravských flyšových hornin. Témuž pracovníku a K. Kropáčovi (UP Olomouc) jsme zavázáni za recenzní připomínky, které přispěly k vylepšení rukopisu.

\section{Literatura}

Bingen B, Griffin WL, Torsvik TH, Saeed A (2005) Timing of Late Neoproterozoic glaciation on Baltica constrained by detrital zircon geochronology in the Hedmark Group, south-east Norway. Terra Nova 17(3): 250-258

Bónová K, Bóna J, Kováčik M, Laurinc D (2016) Heavy minerals from sedimentary rocks of the Malcov Formation and their palaeogeographic implications for evolution of the Magura Basin (Western Carpathians, Slovakia) during the Late Eocene-Late Oligocene. Geol Q 60: 675-694

Bónová K, BónA J, KovÁčIK M, Mıkuš T (2018a) Heavy minerals and exotic pebbles from the Eocene flysch deposits of the Magura Nappe (Outer Western Carpathians, Eastern Slovakia): Their composition and implications on the provenance. Turk J Earth Sci 27: 64-88

Bónová K, Bóna J, Pańczyk M, KováčiK M, Mikuš T, LaURinc D (2019) Origin of deep-sea clastics of the Magura Basin (Eocene Makovica sandstones in the Outer Western Carpathians) with constraints of framework petrography, heavy mineral analysis and zircon geochronology. Palaeogeogr Palaeoclimat Palaeoecol 514: 768-784

BónOVÁ K, MıKuš T, BónA J (2018b) Is Cr-spinel geochemistry enough for solving the provenance dilemma? Case study from the Palaeogene sandstones of the Western Carpathians (Eastern Slovakia). Minerals 8: 543

Bónová K, SPIŠıAK J, BónA J, KovÁčıK M (2017) Chromian spinels from the Magura Unit (Western Carpathians, Eastern Slovakia) - Their petrogenetic and palaeogeographic implications. Geol Q 61: 3-17

Dolniček Z, Kandrnál L, Ulmanová J, VRatislavská E, Hojač $P$ (2019) Historická těžba pelosideritů na lokalitě Koryčanská cesta u Moravan, jižní Chřiby. Bull Mineral Petrolog 27: 304-316

Dolníček Z, Kandrnál L, Ulmanová J, Vratislavská E, HoJAČ $P$ (2020) Mineralogická charakteristika fosforitové konkrece s rodochrozitem z lokality Tabarky, severní Chřiby. Bull Mineral Petrolog 28: 35-43
FItZsimons ICW, HuLscher B (2005) Out of Africa: detrital zircon provenance of central Madagascar and Neoproterozoic terrane transfer across the Mozambique Ocean. Terra Nova 17(3): 224-235

Froelich PN, Arthur MA, Burnett WC, Deakin M, Hensley V, Jahnke R, Kaul L, Kim K-H, Roe K, Soutar A, VATHAKANON C (1988) Early diagenesis of organic matter in Peru continental margin sediments: phosphorite precipitation. Mar Geol 80: 309-343

Gilíková H, Otava J, Stráník Z (2002) Petrografická charakteristika sedimentů magurského flyše na listu mapy 25-312 Holešov. Geol Výzk Mor Slez v r 2001, 9: $26-29$

GRIGSBY JD (1990) Detrital magnetite as a provenance indicator. J Sediment Petrol 60: 940-951

Chlupáč I, Brzobohatý R, Kovanda J, Strání Z (2002) Geologická minulost České republiky. Academia Praha

Kamenetsky VS, Crawford AJ, Meffre S (2001) Factors controlling chemistry of magmatic spinel: An empirical study of associated olivine, Cr-spinel and melt inclusion from primitive rocks. J Petrol 42: 655-671

KROPÁČ K, DolníčEK Z, JANÁL J (2004) Těžké minerály ve zdivu zrríceniny hradu Obřany a okolních horninách (Hostýnské vrchy). Geol výzk Mor Slez v r 2003, 11: 91-93

Mange MA, Morton A (2007) Geochemistry of heavy minerals. In: MANGE MA, WRIGHT DT (eds): Heavy minerals in use. Developments in sedimentology 58: 323-341. Elsevier, Amsterdam

MANGe MA, WRIGHT DA (2007) Heavy minerals in use. Developments in sedimentology 58: 1328 pp. Elsevier, Amsterdam

MATÝSEK D, BuBík M (2012) Fosfát a pelokarbonát z pelitů podslezské jednotky na stavbě silnice R48 u Frýdku-Místku, Česká republika. Geol výzk Mor Slez 19: 88-91

MatÝSEK D, Skupien P (2005) Fosforitové konkrece ve svrchní křídě slezské jednotky. Geol výzk Mor Slez v r 2004, 12: 34-36

MoRTon AC (1978) Heavy minerals. In: Sedimentology. Encyclopedia of Earth Science. Springer, Berlin, Heidelberg

MORTON AC (1987) Influences of provenance and diagenesis on detrital garnet suites in the Paleocene Forties Sandstone, Central North Sea. J Sediment Res 57: 1027-1032

Morton AC, Hallsworth CR (1994) Identifying provenance-specific features of detrital heavy mineral assemblages in sandstones. Sediment Geol 90: 241256

MorTON AC, Hallsworth CR (2007) Stability of detrital heavy minerals during burial diagenesis. In: Mange MA, Wright DT (Eds): Heavy Minerals in Use. Developments in Sedimentology 58: 215-245. Elsevier, Amsterdam

OtAVA J, KREJČi O, Sulovský P (1997) První výsledky studia chemismu granátů pískovců račanské jednotky magurského flyše. Geol výzk Mor Slez v r 1996, 4: 39-42

OtAVA J, KReJči O, Sulovský P (1998) Výsledky studia detritických granátů křídových sedimentů račanské jednotky magurské skupiny. Geol výzk Mor Slez v r 1997, 5: 29-31 
OszczYpKo N, Salata D (2005) Provenance analyses of the Late Cretaceous - Paleocene deposits of the Magura basin (Polish Western Carpathians) - Evidence from a study of the heavy minerals. Acta Geol Polon 55: 237-267

Pober E, FAupl P (1988) The chemistry of detrital chromian spinels and its implications for the geodynamic evolution of the Eastern Alps. Geol Rundsch 77: 641670

POUCHOU JL, PICHOIR F (1985) "PAP" ( $\varphi \rho Z)$ procedure for improved quantitative microanalysis. In: ARMSTRONG JT (ed.) Microbeam Analysis: 104-106. San Francisco Press, San Francisco

RAISWELL R, FISHER QJ (2000) Mudrock-hosted carbonate concretions: a review of growth mechanisms and their influence on chemical and isotopic composition. J Geol Soc London 157: 239-251

SLANSKY M (1986) Geology of sedimentary phosphates. North Oxford Academic, London

Smale D, Morton AC (1988) Heavy mineral suites of core samples from the McKee Formation (Eocene-Lower Oligocene), Taranaki: implications for provenance and diagenesis. New Zeal J Geol Geophys 30: 299-306
Stalder M, RozendaAl A (2004) Apatite nodules as an indicator of depositional environment and ore genesis for the Mesoproterozoic Broken Hill-type Gamsberg Zn$\mathrm{Pb}$ deposit, Namaqua Province, South Africa. Miner Deposita 39: 189-203

Stormer JCJR, Pierson MJ, TACker RC (1993) Variation of $\mathrm{F}$ and $\mathrm{Cl} \mathrm{X}$-ray intensity due to anisotropic diffusion of apatite during electron microprobe analysis. Am Mineral 78: 641-648

STRÁNík Z (1993) Flyšové pásmo Západních Karpat, autochtonní mesozoikum a paleogén na Moravě a ve Slezsku. In Pěıchystal A, Obstová V, Suk M (eds) Geologie Moravy a Slezska: 107-122. Prírodovědecká fakulta Masarykovy univerzity Brno

Stráník Z, Hrouda F, Otava J, Gilíková H, Švábenická L (2007) The Upper Oligocene-Lower Miocene Krosno lithofacies in the Carpathian Flysch Belt (Czech Republic): sedimentology, provenance and magnetic fabrics. Geol Carpath 58(4): 321-332

Zapletal J, BLÁHová Z, Dolní̌EK Z (2012) K provenienci spodnokarbonských drob použitých jako stavební kámen pro jižní věž kostela sv. Mořice v Olomouci. Zpr Vlast Muz Olom, Vědy prír 303: 59-66 